\title{
A time-dependent photochemical model for Titan's atmosphere and the origin of $\mathrm{H}_{2} \mathrm{O}^{\star}$
}

\author{
L. M. Lara ${ }^{1}$, E. Lellouch ${ }^{2}$, M. González ${ }^{1}$, R. Moreno ${ }^{2}$, and M. Rengel ${ }^{3}$ \\ 1 Instituto de Astrofísica de Andalucía - CSIC, c/ Glorieta de la Astronomía s/n, 18008 Granada, Spain \\ e-mail: lara@iaa.csic.es \\ 2 LESIA, Observatoire de Paris-Meudon, 92195 Meudon Principal Cedex, France \\ 3 Max-Planck-Institut für Sonnensystemforschung, Max-Planck-Str. 2, 37191 Katlenburg-Lindau, Germany
}

Received 19 November 2013 / Accepted 17 April 2014

\begin{abstract}
Context. Titan's stratosphere contains oxygen compounds $\left(\mathrm{CO}, \mathrm{CO}_{2}\right.$, and $\left.\mathrm{H}_{2} \mathrm{O}\right)$, implying an external source of oxygen whose nature is still uncertain. Recent observations from the Herschel Space Observatory using the HIFI and PACS instruments and the Cassini/CIRS, as well as steady-state photochemical modeling indicate that the amounts of $\mathrm{CO}_{2}$ and $\mathrm{H}_{2} \mathrm{O}$ in Titan's stratosphere may imply inconsistent values of the $\mathrm{OH} / \mathrm{H}_{2} \mathrm{O}$ input flux, and that the oxygen source is time-variable.

Aims. We attempt to reconcile the $\mathrm{H}_{2} \mathrm{O}$ and $\mathrm{CO}_{2}$ observed profiles in Titan's atmosphere by using an updated photochemical scheme and developing several time-dependent scenarios for the influx/evolution of oxygen species.

Methods. We use a time-dependent photochemical model of Titan's atmosphere to calculate effective lifetimes and the response of Titan's oxygen compounds to changes in the oxygen input flux. Two variants for the C-H-O chemical network are considered. We investigate a time-variable Enceladus source and the evolution of material delivered by a cometary impact.

Results. We find that the effective lifetime of $\mathrm{H}_{2} \mathrm{O}$ in Titan's atmosphere is only a factor of six shorter than that of $\mathrm{CO}_{2}$ and exceeds $10 \mathrm{yr}$ below $200 \mathrm{~km}$. A time-variable Enceladus source, involving a decrease by a factor of 5-20 in the $\mathrm{OH} / \mathrm{H}_{2} \mathrm{O}$ flux over the last few centuries, shows promise in explaining the relative $\mathrm{CO}_{2} / \mathrm{H}_{2} \mathrm{O}$ profiles. However, if the previous measurements from the Herschel Space Observatory are representative of Titan's atmospheric water, an additional $\mathrm{H}_{2} \mathrm{O}$ loss to the haze term is needed to bring the model in full agreement with the data. In an alternate situation, $\mathrm{CO}_{2}$ production following a cometary impact that occurred at least 220-300 yr ago can in principle explain the $\mathrm{CO}_{2}$ "excess" in Titan's stratosphere, but this scenario is highly unlikely, given the estimates of the impact rate at Titan.
\end{abstract}

Key words. planets and satellites: atmospheres - planets and satellites: individual: Titan - planets and satellites: composition

\section{Introduction}

The presence of water vapor in the stratosphere of the outer planets, as established by ISO, has raised the question of the origin of external oxygen in these reducing environments. While the gross similarity of the $\mathrm{H}_{2} \mathrm{O}$ fluxes into the four giant planets (Feuchtgruber et al. 1997) might have been taken as evidence that micrometeorite ablation is the dominant source, recent observations, especially using the Herschel Space Observatory (Herschel hereafter), have revealed a different picture. These datasets outline the role of recent cometary impacts in delivering $\mathrm{H}_{2} \mathrm{O}, \mathrm{CO}$ and $\mathrm{CO}_{2}$ to Jupiter and $\mathrm{CO}$ in Neptune and possibly Saturn and that of Enceladus' activity in feeding Saturn's upper atmosphere with water vapor (see Cavalié et al. 2013, and references therein).

Following the original detection by ISO (Coustenis et al. 1998), the presence of water vapor has been recently revived by measurements of the $\mathrm{H}_{2} \mathrm{O}$ vertical profile by both Cassini/CIRS (Cottini et al. 2012) and Herschel/PACS and Herschel/HIFI (Moreno et al. 2012) at Titan. These studies differed significantly in the amounts of $\mathrm{H}_{2} \mathrm{O}$ implied by typically a factor of 4-5 at $115 \mathrm{~km}$. Based on photochemical modeling, Moreno et al. (2012) found that the modeled $\mathrm{CO}_{2}$ abundance at $100-200 \mathrm{~km}$

* Tables 1-3 are available in electronic form at http://www . aanda.org is too small by a factor of $\sim 10$ compared to the observed value of $10-20 \mathrm{ppb}$ when the $\mathrm{H}_{2} \mathrm{O}$ influx is adjusted to match their water profile. Noting that the atmospheric lifetimes of $\mathrm{CO}_{2}$ and $\mathrm{H}_{2} \mathrm{O}$ are very different, Moreno et al. (2012) proposed that the discrepancy could be solved by invoking a variable input flux over timescales of tens to hundreds of years and tentatively favored Enceladus' plume activity as the source of Titan's external oxygen.

Most recently, Dobrijevic et al. (2014) presented a fully coupled oxygen-nitrogen-hydrocarbon model, in which a number of reactions had been updated or added since the previous models by Hörst et al. (2008) and Moreno et al. (2012); in particular, reactions between $\mathrm{N}$ - and O-bearing species were considered. They confirmed the essential conclusion of Moreno et al. (2012) in that the measured $\mathrm{H}_{2} \mathrm{O}$ profile is inconsistent with the $\mathrm{CO}_{2}$ abundance, although the disagreement was reduced to a factor of 4. Dobrijevic et al. (2014) found that reconciliation was possible if water abundances reported by Cottini et al. (2012) are correct instead; although in this situation and for an Enceladus source, their model tended to overpredict the thermospheric abundance of $\mathrm{H}_{2} \mathrm{O}$ when compared to the globally averaged upper limit determined by Cui et al. (2009). Dobrijevic et al. (2014) also find that the deposition altitude of the $\mathrm{OH} / \mathrm{H}_{2} \mathrm{O}$ flux $(750 \mathrm{~km}$, which is representative of micrometeorite ablation, vs. the top of the atmosphere, which is characteristic 
of an Enceladus source) influences the flux required to reproduce the observed $\mathrm{H}_{2} \mathrm{O}$ and $\mathrm{CO}_{2}$ profiles and the abundance of secondary $\mathrm{N}-\mathrm{O}$ and $\mathrm{H}-\mathrm{N}-\mathrm{O}$ species.

In this work, by means of a time-dependent photochemical model, we explore in more details the scenario of a variable oxygen source at Titan to see whether it is a plausible explanation to the " $\mathrm{H}_{2} \mathrm{O} / \mathrm{CO}_{2}$ puzzle". We consider both the $\mathrm{H}_{2} \mathrm{O}$ profiles derived from Cassini/CIRS (Cottini et al. 2012) and from Herschel (Moreno et al. 2012). In addition, we study a scenario when Titan might have suffered a cometary impact in the past by bringing oxygen species into its atmosphere.

\section{Model description}

The number density $n$ at altitude $z$ for every constituent $i$ at time $t$ is solved by means of the usual continuity equations in spherical geometry:

$$
\frac{\partial n_{i}}{\partial t}=P_{i}-n_{i} l_{i}-\frac{1}{r^{2}} \frac{\partial}{\partial r}\left(r^{2} \Phi_{i}\right)
$$

where $\Phi_{i}$ can be expressed as

$$
\begin{aligned}
\Phi_{i}= & -n_{i} D_{i}\left(\frac{1}{n_{i}} \frac{\partial n_{i}}{\partial z}+\frac{1+\alpha_{i}}{T} \frac{\partial T}{\partial z}+\frac{1}{H_{i}}\right) \\
& -n_{i} K\left(\frac{1}{n_{i}} \frac{\partial n_{i}}{\partial z}+\frac{1}{T} \frac{\partial T}{\partial z}+\frac{1}{H}\right) .
\end{aligned}
$$

The variable $n_{i}, P_{i}$, and $l_{i}$ are the number density, volumic production rate, and volumic specific loss rate, and $r=R_{0}+z$, where $R_{0}=2575 \mathrm{~km}$ and $z$ runs from 34 to $1432 \mathrm{~km}$ with an altitude bin size of $1 \mathrm{~km}$. The parameter $D_{i}$ is the molecular diffusion coefficient, $T$ is temperature, $H_{i}$ and $H$ are the individual and atmospheric scale heights, $K(z)$ is the eddy diffusion coefficient, and, $\alpha_{i}$ is the thermal diffusion coefficient. The equations are solved for methane $\mathrm{CH}_{4}$, methyl radical $\mathrm{CH}_{3}$, acetylene $\mathrm{C}_{2} \mathrm{H}_{2}$, ethylene $\mathrm{C}_{2} \mathrm{H}_{4}$, ethane $\mathrm{C}_{2} \mathrm{H}_{6}$, methyl acetylene $\mathrm{CH}_{3} \mathrm{C}_{2} \mathrm{H}$, propane $\mathrm{C}_{3} \mathrm{H}_{8}$, diacetylene $\mathrm{C}_{4} \mathrm{H}_{2}$, atomic hydrogen $\mathrm{H}$, molecular hydrogen $\mathrm{H}_{2}$, carbon monoxide $\mathrm{CO}$, carbon dioxide $\mathrm{CO}_{2}$, $\mathrm{O}\left({ }^{3} \mathrm{P}\right)$, formyl $\mathrm{HCO}$, formaldehyde $\mathrm{H}_{2} \mathrm{CO}$, hydroxyl $\mathrm{OH}, \mathrm{CH}$, $\mathrm{C}_{2}, \mathrm{C}_{4} \mathrm{H}, \mathrm{C}_{3} \mathrm{H}_{5}, \mathrm{C}_{2} \mathrm{H},{ }^{1} \mathrm{CH}_{2},{ }^{3} \mathrm{CH}_{2}, \mathrm{C}_{2} \mathrm{H}_{3}, \mathrm{C}_{2} \mathrm{H}_{5}, \mathrm{C}_{4} \mathrm{H}_{2}^{*}, \mathrm{C}_{4} \mathrm{H}_{3}$, $\mathrm{O}\left({ }^{1} \mathrm{~S}\right), \mathrm{O}\left({ }^{1} \mathrm{D}\right), \mathrm{CH}_{3} \mathrm{O}$, and $\mathrm{CH}_{3} \mathrm{CO}$.

We use a fully implicit finite difference scheme (unconditionally stable) with a variable $\Delta t$ time step to accomodate the large range of characteristic times (i.e., turbulent transport, molecular diffusion, and chemical times for all the species).

The model, which originally derives from Lara et al. (1996), has been updated in several ways. First we include new reaction rates for the hydrocarbons (see Table 1). Second, for the chemical network involving oxygen species, we consider two schemes: (i) the one from (Hörst et al. 2008, hereafter H08), which was also used by (Moreno et al. 2012, see Table 2); and (ii) a modified C-H-O chemical scheme, which results from common reactions in Dobrijevic et al. (2014) and in Hörst et al. (2008) that are updated with rate coefficients in Dobrijevic et al. (2014), and additional reactions from Dobrijevic et al. (2014) that only involve the hydrocarbons and oxygen species listed above. Specifically, this means that we ignore reactions coupling $\mathrm{N}$ and $\mathrm{O}$ chemistry. This is justified by the fact that we are primarily interested by the profiles of $\mathrm{CO}_{2}$ and $\mathrm{H}_{2} \mathrm{O}$ and not the abundances of secondary N-O-H species. In particular, the reaction $\mathrm{OH}+\mathrm{N}\left({ }^{4} \mathrm{~S}\right)$ in the reaction scheme coupling $\mathrm{N}$ and $\mathrm{O}$ species (which in the C-H-N-O chemistry by Dobrijevic et al. (2014) is important above $1000 \mathrm{~km}$ to produce NO) only represents $0.003 \%$ of the $\mathrm{OH}$ column integrated loss in the $\mathrm{C}-\mathrm{H}-\mathrm{O}$ chemical network for typical $\mathrm{OH}$ and $\mathrm{N}\left({ }^{4} \mathrm{~S}\right)$ vertical profiles. Regarding water, the main additional loss term that involves nitrogen is $\mathrm{H}_{2} \mathrm{O}+\mathrm{N}\left({ }^{2} \mathrm{D}\right)$, but this only accounts for $0.85 \%$ of the total water loss rate given typical profiles of $\mathrm{H}_{2} \mathrm{O}$ and $\mathrm{N}\left({ }^{2} \mathrm{D}\right)$. Reactions for this simplified chemical scheme (hereafter L14), with regard to Dobrijevic et al. (2014) are listed in Table 3.

Finally, compared to Lara et al. (1996), a more recent treatment of the UV transmission in the haze layer is considered. For this, we have adopted the results shown in Fig. 2 of Krasnopolsky (2009), which in fact do not noticeably differ from the approximation seen in Yung et al. (1984) as used in Lara et al. (1996) and in Moreno et al. (2012).

Here we retain the same treatment for the condensation processes, as in Lara et al. (1996), and adopt the eddy diffusion coefficient $\left(K_{2}\right)$ from Moreno et al. (2012), Following Hörst et al. (2008), the $\mathrm{O}\left({ }^{3} \mathrm{P}\right)$ flux is introduced in the model in a layer with a peak at $1100 \mathrm{~km}$. The magnitude of the $\mathrm{O}\left({ }^{3} \mathrm{P}\right)$ flux normally drives the $\mathrm{CO}$ abundance. However, due to its extremely long lifetime (several $10^{8} \mathrm{yr}$ ), reaching a chemical balance on CO needs a long integration time (e.g. Dobrijevic et al. 2014). Instead the $\mathrm{CO}$ mixing ratio is prescribed hereat its observed value, $5.1 \times 10^{-5}$ (Gurwell 2004), at the model's lower boundary; the abundance vertical profile is then computed in the model, and the $\mathrm{O}\left({ }^{3} \mathrm{P}\right)$ flux is then unimportant for determining the $\mathrm{CO}_{2}$ and $\mathrm{H}_{2} \mathrm{O}$ profiles. As detailed below, we investigate the sensitivity of the results to form $\left(\mathrm{OH}\right.$ vs. $\left.\mathrm{H}_{2} \mathrm{O}\right)$ and the deposition profile of the water influx.

Boundary conditions at $34 \mathrm{~km}$ are set as follows: for condensible species, the mixing ratio is the maximum value allowed by the saturation laws, which is zero supersaturation; for noncondensible species, either they are in local photochemical equilibrium and the number density is computed as the quotient of the production and specific loss, or they have a maximum flux through the lower boundary. At $1432 \mathrm{~km}$, only $\mathrm{H}$ and $\mathrm{H}_{2}$ are allowed to escape according to the Jeans formulation, whereas the other species are in diffusive equilibrium (excluding $\mathrm{OH} / \mathrm{H}_{2} \mathrm{O}$ in the case that they have an inward flux due to the Enceladus plume activity).

The thermal profile used for our computation is a combination of (i) the temperatures measured by Huygens/HASI (Fulchignoni et al. 2005) in the troposphere at altitudes between 0-140 km; (ii) the disk-averaged Cassini/CIRS stratospheric temperatures (Vinatier et al. 2010) at altitudes between 140-500 km; (iii) the Cassini/INMS retrieved temperatures (i.e. $155 \mathrm{~K}$ as average, de La Haye et al. (2007)) at altitudes between $1000-1500 \mathrm{~km}$; and (iv) a decreasing temperature from $165 \mathrm{~K}$ to $155 \mathrm{~K}$ at altitudes between 500 and $1000 \mathrm{~km}$.

Our study aims at reproducing (i) the $\mathrm{H}_{2} \mathrm{O}$ vertical profiles in Moreno et al. (2012) and Cottini et al. (2012) with both chemical schemes, for $\mathrm{H} 08$ and L14; and (ii) the $\mathrm{CO}_{2}$ stratospheric abundance from Cassini/CIRS data (de Kok et al. 2007).

\section{3. $\mathrm{OH}$ versus $\mathrm{H}_{2} \mathrm{O}$ external source}

Both Hörst et al. (2008) and (Moreno et al. 2012, who considered the H08 chemical scheme) concluded that the OH vs. $\mathrm{H}_{2} \mathrm{O}$ form of the water input is unimportant when fitting the stratospheric water abundance, since a balance is established between $\mathrm{OH}$ and $\mathrm{H}_{2} \mathrm{O}$, due to the photolysis of water and reactions between $\mathrm{OH}$ and $\mathrm{CH}_{3}$ or $\mathrm{OH}$ and $\mathrm{CH}_{4}$ recycling water. They also found that fluxes required to reproduce a given $\mathrm{H}_{2} \mathrm{O}$ profile are independent on the precise deposition profile (i.e., deposition at the top of the atmosphere as appropriate or in a Chapman 
Table 4. Steady-state models results for an $\mathrm{OH}$ and $\mathrm{H}_{2}$ flux at the top of the atmosphere.

\begin{tabular}{lccccc}
\hline \hline $\begin{array}{l}\text { Observed } \\
\text { profile }\end{array}$ & $\begin{array}{c}\text { Chemical } \\
\text { network }\end{array}$ & $\begin{array}{c}\mathrm{OH} \text { flux } \\
\left(\mathrm{cm}^{-2} \mathrm{~s}^{-1}\right)\end{array}$ & $\begin{array}{c}\mathrm{H}_{2} \mathrm{O} \\
\left(\mathrm{cm}^{-2} \mathrm{~s}^{-1}\right)\end{array}$ & $\begin{array}{c}\mathrm{O}\left({ }^{3} \mathrm{P}\right) \text { flux } \\
\left(\mathrm{cm}^{-2} \mathrm{~s}^{-1}\right)\end{array}$ & $\begin{array}{c}\mathrm{CO}_{2} \text { mixing ratio } \\
\text { at 150 km }\end{array}$ \\
\hline$S_{a}$ (Moreno et al. 2012) & $\mathrm{H} 08$ & $2.4 \times 10^{5}$ & 0 & $1.6 \times 10^{6}$ & $6.2 \times 10^{-10}$ \\
$S_{a}$ (Moreno et al. 2012) & $\mathrm{L} 14$ & $3.2 \times 10^{5}$ & 0 & $1.6 \times 10^{6}$ & $8.7 \times 10^{-10}$ \\
$S_{a}$ (Moreno et al. 2012) & $\mathrm{L} 14$ & 0 & $2.6 \times 10^{5}$ & $1.6 \times 10^{6}$ & $8.7 \times 10^{-10}$ \\
CIRS (Cottini et al. 2012) & $\mathrm{H} 08$ & $9.0 \times 10^{5}$ & 0 & $1.0 \times 10^{6}$ & $2.5 \times 10^{-9}$ \\
CIRS (Cottini et al. 2012) & L14 & $1.2 \times 10^{6}$ & 0 & $1.6 \times 10^{6}$ & $3.3 \times 10^{-9}$ \\
CIRS (Cottini et al. 2012) & L14 & 0 & $9.8 \times 10^{5}$ & $1.6 \times 10^{6}$ & $3.3 \times 10^{-9}$ \\
\hline
\end{tabular}

layer near $750 \mathrm{~km}$ ). On the other hand, Dobrijevic et al. (2014) found large variations in the required $\mathrm{H}_{2} \mathrm{O} / \mathrm{OH}$ flux depending on its $\mathrm{H}_{2} \mathrm{O}$ vs. $\mathrm{OH}$ form and on its altitude deposition. For example, Table 2 of Dobrijevic et al. (2014) shows that a given flux produces $\sim 33 \%$ more $\mathrm{H}_{2} \mathrm{O}$ in Titan's atmosphere for meteoritic ablation near $750 \mathrm{~km}$ (cases "IM1" and "IM4"), when it is deposited in the form of $\mathrm{H}_{2} \mathrm{O}$ compared to the case where it is deposited as $\mathrm{OH}$. The difference becomes larger in the case of water deposition at the top of the atmosphere (cases "IE1" and "IE2"), where a $\mathrm{OH}$ flux (compared to $\mathrm{H}_{2} \mathrm{O}$ flux) that is twice as large is needed to produce the same amount of $\mathrm{H}_{2} \mathrm{O}$.

We re-examined these issues with the new treatment of the UV transmission within the haze and the new chemical network (L14). For this, we computed steady-state solutions by fine-tuning the $\mathrm{OH} / \mathrm{H}_{2} \mathrm{O}$ influx to match the available observations (HIFI+PACS in Moreno et al. (2012) and Cassini/CIRS by Cottini et al. (2012)). Table 4 summarizes the required fluxes to match the $\mathrm{H}_{2} \mathrm{O}$ determinations from Herschel and Cassini/CIRS by using the two sets of chemistry and water influx in the form of either $\mathrm{OH}$ or $\mathrm{H}_{2} \mathrm{O}$. (Only cases of deposition at the top of the atmosphere are summarized in Table 4.)

Although we do find with our simplified L14 scheme values that are similar to Dobrijevic et al. (2014), Table 4 indicates that an influx in the form of $\mathrm{H}_{2} \mathrm{O}$ entering Titan's atmosphere is more "efficient" at producing $\mathrm{H}_{2} \mathrm{O}$ in Titan's atmosphere than an $\mathrm{OH}$ flux; the difference is only about $20 \%$ (vs. a factor $\sim 2$ in Dobrijevic et al. 2014). Moreover, for a given form of deposition $\left(\mathrm{OH}\right.$ or $\mathrm{H}_{2} \mathrm{O}$ ), we do not find any significant difference between the required fluxes as a function of deposition profile, as the associated Titan $\mathrm{H}_{2} \mathrm{O}$ profiles for a given flux and the two scenarios of deposition profiles are identical up to $750 \mathrm{~km}$. In contrast, the profiles start to diverge above this altitude as seen in Figs. 12 and 13 of Moreno et al. (2012), so that measurements of the $\mathrm{H}_{2} \mathrm{O}$ mole fraction in the upper atmosphere could help constrain the Enceladus in contrast to micrometeoroid ablation origin of the external flux. We are unsure of the cause of the discrepancy with Dobrijevic et al. (2014), and we do not understand why their required fluxes are so dependent on the altitude deposition profile. Indeed, we estimated that the non-inclusion of the N-O coupling has a negligible effect of the fluxes required to match a given $\mathrm{H}_{2} \mathrm{O}$ profile above, and the latter authors do not explicitly show a case with the $\mathrm{N}-\mathrm{O}$ chemistry turned off for comparison. Likely reasons of the discrepancy may be related to significantly different profiles of the $\mathrm{C}-\mathrm{H}$ and $\mathrm{C}-\mathrm{H}-\mathrm{N}$ species profiles computed in (Dobrijevic et al. 2014, not shown therein) and ours.

\section{Lifetimes}

Moreno et al. (2012) could not simultaneously fit the stratospheric abundance of $\mathrm{H}_{2} \mathrm{O}$ measured with Herschel and of $\mathrm{CO}_{2}$ (de Kok et al. 2007) with the same $\mathrm{OH}$ and $\mathrm{O}\left({ }^{3} \mathrm{P}\right)$ flux. They proposed that the discrepancy could be solved by invoking a time-variable input flux. They based their argument on the different atmospheric lifetimes of $\mathrm{H}_{2} \mathrm{O}$ and $\mathrm{CO}_{2}$. This had been already found by Wilson \& Atreya (2004), who reported chemical lifetimes of 4.1 and $697 \mathrm{yr}$ at $300 \mathrm{~km}$ for $\mathrm{H}_{2} \mathrm{O}$ and $\mathrm{CO}_{2}$. Moreno et al. (2012) obtained similar numbers (9 yr and $450 \mathrm{yr}$ ) for the "column-integrated" lifetime, which is defined by dividing the column density by the vertically-integrated chemical loss including photolysis. For $\mathrm{CO}_{2}$, this lifetime was comparable to the vertical transport time down to the condensation level (360 yr). However, these approaches give either an estimate of the lifetime against chemical loss at some level or a global estimate of the atmospheric residence time of a species in the atmosphere, but they do not handle the fact that the time evolution of the atmospheric mixing ratios depends on both chemical and transport processes, which may show important variations with altitude.

To account for this, we first used our time-dependent model as described, to study the response of oxygen species to an abrupt change in the oxygen source rate. For this, we initialized the oxygen compounds to the steady state solution profiles obtained in the case of the $\mathrm{OH}$ Enceladus source (i.e, deposited at the top of the atmosphere) by considering the two variants of the oxygen chemistry (H08 and L14). The steady state $\mathrm{OH}$ fluxes required to match the $\mathrm{H}_{2} \mathrm{O}$ Herschel profile are given in Table 4, and an $\mathrm{O}\left({ }^{3} \mathrm{P}\right)$ flux of $1.6 \times 10^{6} \mathrm{~cm}^{-2} \mathrm{~s}^{-1}$ is used. Then, for each case, the oxygen sources are cut to zero and the oxygen species evolve with time. For each species, we define the altitude-dependent "effective lifetime" as the time after which the mixing ratio has decreased by a factor $e$ at the considered altitude. This definition is clearly only approximate since the time evolution does not follow a simple exponential decay. Results for the H08 chemical network are shown in Fig. 1 for all oxygen species but $\mathrm{CO}$ (which has a very long lifetime at all levels). It has to be pointed out that the "effective lifetimes" for every species are approximately the same when using the H08 or the L14 chemical network.

For comparison, Fig. 2 shows the altitude-dependent lifetimes associated to the different processes considered in the model for some oxygen species $\left(\mathrm{CO}_{2}, \mathrm{H}_{2} \mathrm{O}, \mathrm{H}_{2} \mathrm{CO}, \mathrm{O}\left({ }^{3} \mathrm{P}\right)\right.$ and $\mathrm{OH}$ ): photolysis, gas-gas chemical reactions (for which the lifetime is defined at each altitude $j$ as the minimum of $1 / l_{i, j}^{k}$, $k$ that represents all of the reactions consuming the species $i$ at altitude $j$ ), molecular diffusion, and turbulent transport. For $\mathrm{H}_{2} \mathrm{O}$, the photolytic lifetime (which drives the overall chemical lifetime) increases from $\sim 0.5 \mathrm{yr}$ at the top of the atmosphere to $\sim 10 \mathrm{yr}$ at $200 \mathrm{~km}$ and further increases at lower levels. The ratio of the chemical lifetime of $\mathrm{CO}_{2}$ to that of $\mathrm{H}_{2} \mathrm{O}$ is a factor of 100 above $400 \mathrm{~km}$. All these numbers are consistent with the above estimates of the "column-integrated" chemical lifetimes.

Nonetheless, the time evolution of the at a given level is more properly described by the effective lifetimes (Fig. 1). For $\mathrm{H}_{2} \mathrm{O}$, it increases regularly from $\sim 0.1 \mathrm{yr}$ at the top to $10 \mathrm{yr}$ 


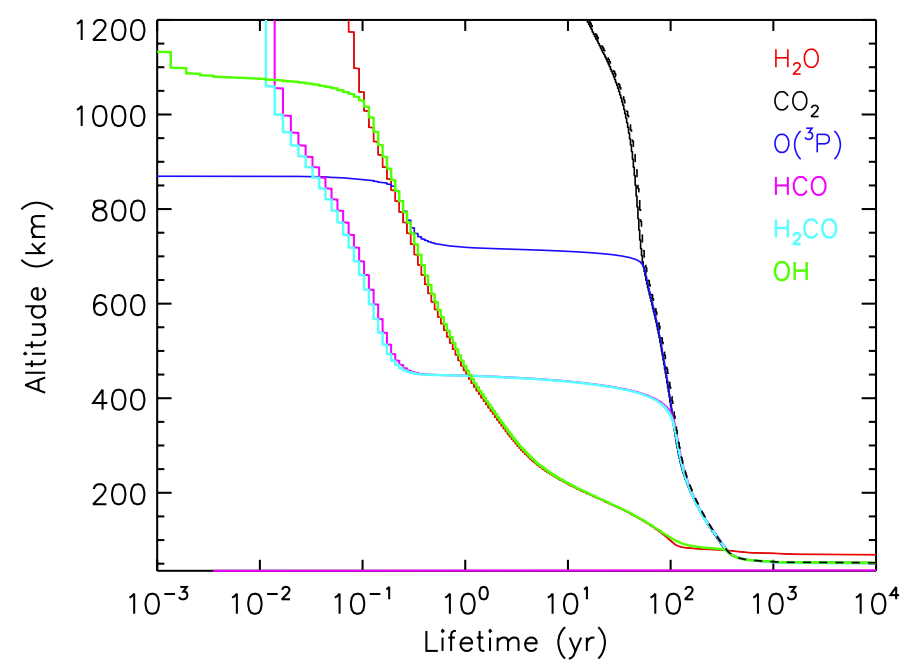

Fig. 1. Effective lifetimes (see text for definition) as a function of altitude for oxygen species. These are calculated for $\mathrm{OH}$ and $\mathrm{O}\left({ }^{3} \mathrm{P}\right)$ input fluxes of $2.4 \times 10^{5}$ and $1.6 \times 10^{6} \mathrm{~cm}^{-2} \mathrm{~s}^{-1}$, respectively, and the H08 chemical network. The effective lifetime for $\mathrm{CO}_{2}$ for an enhanced input $\mathrm{OH}$ flux $=5.1 \times 10^{6} \mathrm{~cm}^{-2} \mathrm{~s}^{-1}$ (needed to match the $\mathrm{CO}_{2}$ profile) is also shown as a dashed black line.

at $200 \mathrm{~km}$ and about $100 \mathrm{yr}$ at $80 \mathrm{~km}$ (at deeper levels, $\mathrm{H}_{2} \mathrm{O}$ is constrained to very small amounts by condensation, so the apparent "divergence" of the lifetime is not meaningful). For $\mathrm{CO}_{2}$, the effective lifetime increases from $20 \mathrm{yr}$ at the top of the atmosphere to $400 \mathrm{yr}$ at $\sim 80 \mathrm{~km}$ before entering in the condensation region. The $\mathrm{OH}$ lifetime is very short in the upper atmosphere $(>1000 \mathrm{~km})$ but it tracks that of $\mathrm{H}_{2} \mathrm{O}$ from which it is photochemically produced below this altitude. Similarly, the lifetimes of $\mathrm{O}\left({ }^{3} \mathrm{P}\right)$ and $\mathrm{HCO} / \mathrm{H}_{2} \mathrm{CO}$ are short below 850 and $450 \mathrm{~km}$ and progressively increase to follow that of $\mathrm{CO}_{2}$ below 700 and $400 \mathrm{~km}$, respectively. For these four species, the long lifetimes in the lower atmosphere have, however, little significance because the involved amounts are very small. In addition to the altitude-dependent effective lifetime, it is useful to similarly define the column-averaged effective lifetime as the time after which the column density has decreased by a factor $e$. These column-average lifetimes are found to be $287 \mathrm{yr}$, $51 \mathrm{yr}, 12 \mathrm{~d}, 10 \mathrm{~d}, 5 \mathrm{~h}$, and $1 \mathrm{~h}$ for $\mathrm{CO}_{2}, \mathrm{H}_{2} \mathrm{O}, \mathrm{H}_{2} \mathrm{CO}, \mathrm{HCO}, \mathrm{OH}$, and $\mathrm{O}\left({ }^{3} \mathrm{P}\right)$, respectively. The most important result for our purpose is that the effective lifetimes for $\mathrm{CO}_{2}$ and $\mathrm{H}_{2} \mathrm{O}$ differ by less than a factor of 6 , regardless of the photochemical scheme and the initial profile to which time-evolution is applied.

\section{Evolution of the $\mathrm{H}_{2} \mathrm{O}$ and $\mathrm{CO}_{2}$ profiles under changes of the input flux}

Running the time-dependent model shows that all species except $\mathrm{CO}, \mathrm{CO}_{2}$, and $\mathrm{H}_{2} \mathrm{O}$ decrease to molar fractions $<10^{-12}$ in less than 10 yr upon an abrupt cut-off of the oxygen input fluxes. While the shape of the $\mathrm{CO}_{2}$ profile is conserved as the $\mathrm{CO}_{2}$ abundance slowly declines with time, the $\mathrm{H}_{2} \mathrm{O}$ profile strongly evolves. As a consequence of the quick altitude-varying lifetime, the $\mathrm{H}_{2} \mathrm{O}$ depletion proceeds much more rapidly at upper levels, causing a local maximum ("kink") of the $\mathrm{H}_{2} \mathrm{O}$ mixing ratio in the $125-160 \mathrm{~km}$ altitude range to appear after $\sim 10 \mathrm{yr}$. This behavior occurs for both the H08 and L14 chemical networks, and initial water profiles in agreement with either Herschel or Cassini/CIRS data. Figure 3 shows the evolution of the $\mathrm{CO}_{2}$ and

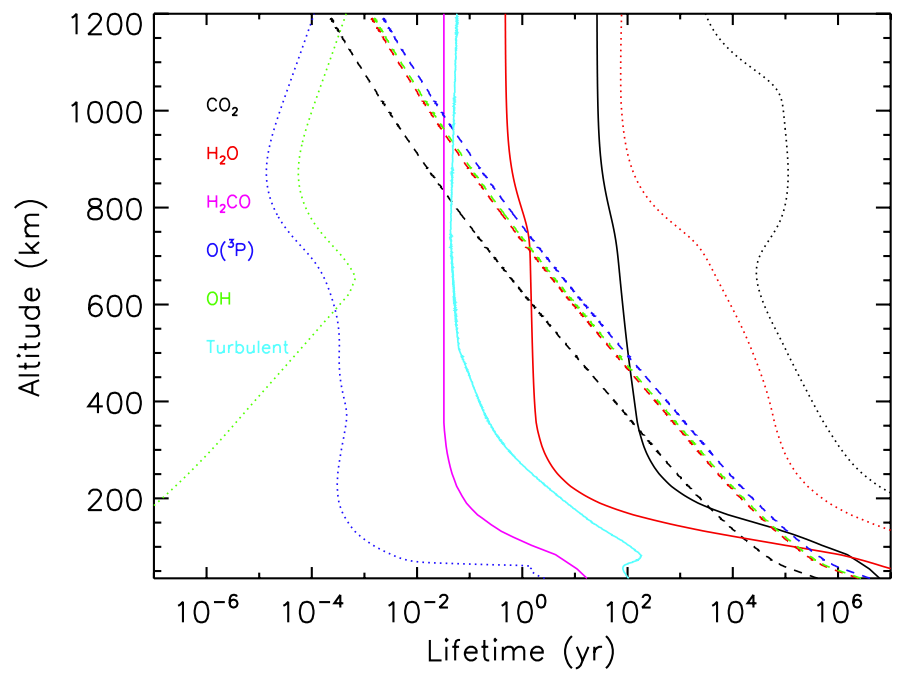

Fig. 2. Lifetimes for different processes. Solid lines: photolytic lifetime Dotted lines: chemical (gas-gas) lifetime. Dashed lines: molecular diffusion timescale. $\left(H_{i}^{2} / D_{i}\right)$. The characteristic time for turbulent transport $\left(H^{2} / K\right)$ is also shown. This figure makes use of the H08 chemical scheme, where $\mathrm{OH}$ photolysis is not included, and $\mathrm{H}_{2} \mathrm{CO}$ is only lost via photodissociation.

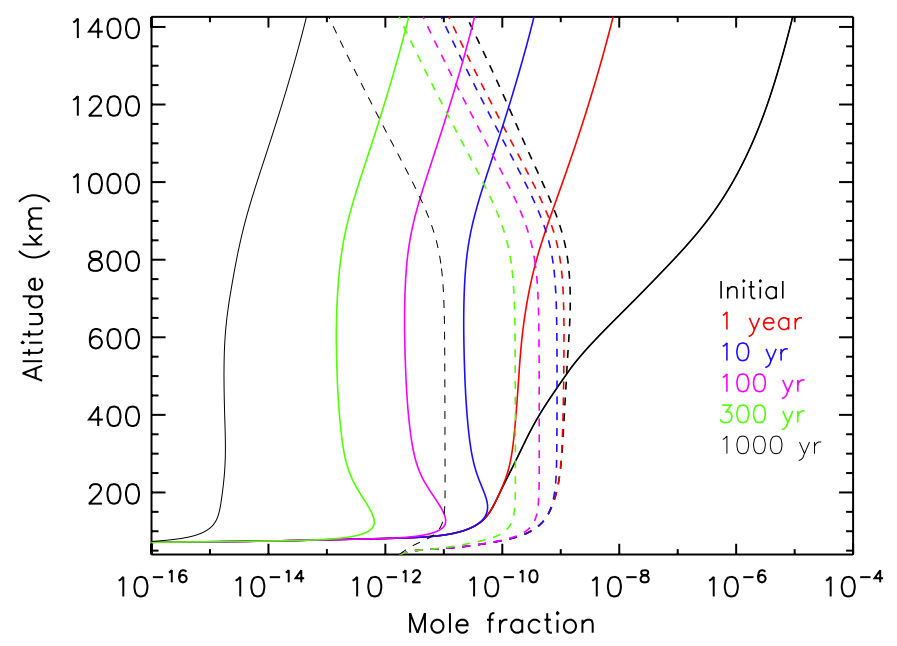

Fig. 3. Time-evolution of oxygen species 1, 10, 100, 300 and $1000 \mathrm{yr}$ after the oxygen sources have been abruptly cut-off. Profiles are initialized at steady-state conditions for $\mathrm{O}\left({ }^{3} \mathrm{P}\right)$ and $\mathrm{OH}$ input fluxes at $1.6 \times 10^{6}$ and $2.4 \times 10^{5} \mathrm{~cm}^{-2} \mathrm{~s}^{-1}$, respectively, matching the $\mathrm{H}_{2} \mathrm{O}$ profile of Moreno et al. (2012). Solid lines refer to $\mathrm{H}_{2} \mathrm{O}$, and dashed lines refer to $\mathrm{CO}_{2}$.

$\mathrm{H}_{2} \mathrm{O}$ profiles for initial conditions that match the $S_{a}$ profile in Moreno et al. (2012) and adopt the H08 chemistry.

\subsection{Time-variable input fluxes}

Builiding on this, we considered a simple scenario for the time evolution of the oxygen fluxes to test the hypothesis of a timevariable Enceladus source being responsible for the "inconsistent" $\mathrm{H}_{2} \mathrm{O}$ and $\mathrm{CO}_{2}$ abundances. Essentially, we assume that the input fluxes have been strong enough in the past to explain the observed $\mathrm{CO}_{2}$ and that they have decreased exponentially since some recent time. We describe the history of the $\mathrm{OH}$ flux as

- for $t<$ current epoch- $t_{0}: \Phi(\mathrm{OH})=\Phi_{0}(\mathrm{OH})$;

- for $t>$ current epoch- $t_{0}: \Phi(\mathrm{OH})=\Phi_{0}(\mathrm{OH}) \times \exp (-(t / \tau))$, 

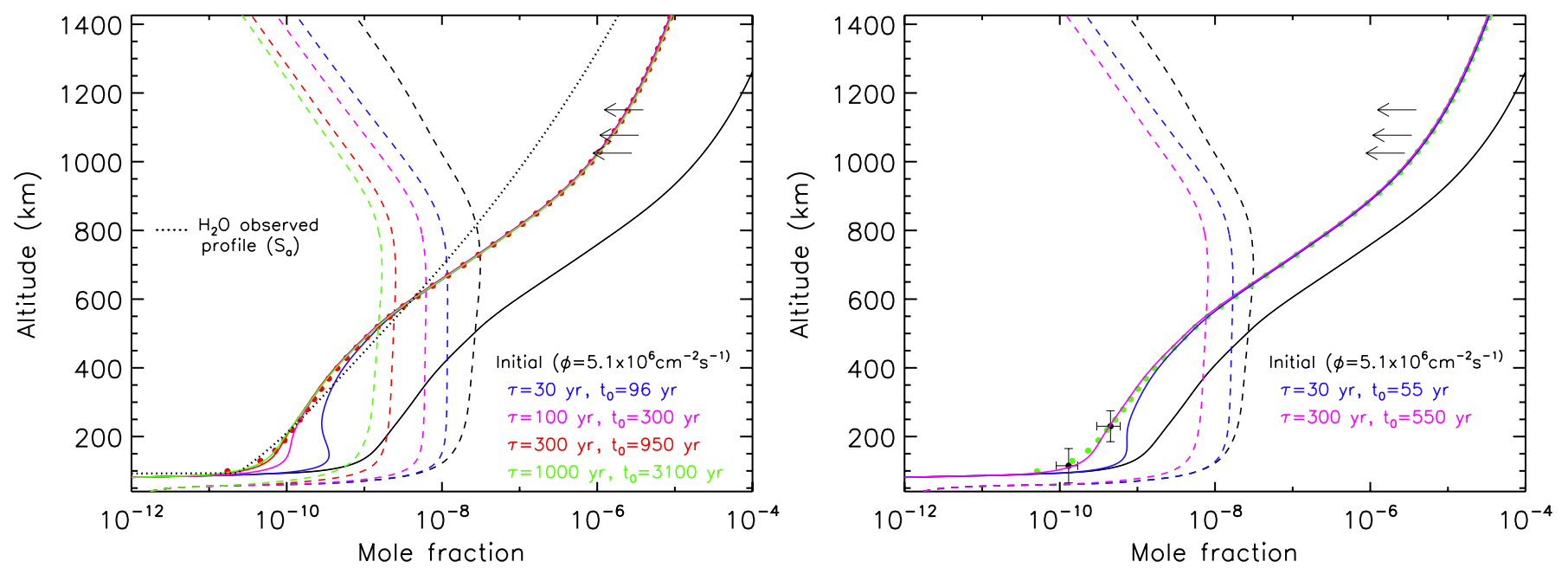

Fig. 4. $\mathrm{H}_{2} \mathrm{O}$ (solid lines) and $\mathrm{CO}_{2}$ (dashed lines) profiles in a time-dependent Enceladus source model, as compared to observations, making use of the $\mathrm{H} 08$ chemical scheme. Left panel: results aimed at fitting the $\mathrm{H}_{2} \mathrm{O}$ observed with Herschel. The profiles are initialized at their steady-state values for a $\mathrm{OH}$ flux of $5.1 \times 10^{6} \mathrm{~cm}^{-2} \mathrm{~s}^{-1}$ (black curves). The different curves correspond to evolution with four different combinations of $\tau$ and $t_{0}$. The red circles show the $\mathrm{H}_{2} \mathrm{O}$ profile in the $\left(\tau=30 \mathrm{yr}, t_{0}=96 \mathrm{yr}\right)$ case calculated in presence of an additional loss of $\mathrm{H}_{2} \mathrm{O}$ to the haze (see text). Right panel: results aimed at fitting the $\mathrm{H}_{2} \mathrm{O}$ observed with Cassini/CIRS. The black curves correspond to the steady state profiles obtained with an $\mathrm{OH}$ flux of $5.1 \times 10^{6} \mathrm{~cm}^{-2} \mathrm{~s}^{-1}$. Evolution of these profiles for two different $\left(\tau, t_{0}\right)$ combinations are shown, as well as the resulting $\mathrm{H}_{2} \mathrm{O}$ profile, when a loss to the haze is taken into account for the $\left(\tau=30 \mathrm{yr}, t_{0}=55 \mathrm{yr}\right)$ case (green dots). Upper limits on $\mathrm{H}_{2} \mathrm{O}$ thermospheric abundance by Cui et al. (2009) are also shown as arrows.

where $t$ is the time elapsed since the onset of the flux decline, which is assumed to have started $t_{0} \mathrm{yr}$ before the current epoch. The model thus has three free parameters: (i) $t_{0}$, the number of years in the past when the input fluxes have started to decrease; (ii) $\Phi_{0}(\mathrm{OH})$, the input flux before it started to decrease; and (iii) $\tau$, the characteristic time of the flux decline. Since we are modeling an Enceladus source, we assume that the $\mathrm{O}\left({ }^{3} \mathrm{P}\right)$ flux follows the same time dependence and fix the $\mathrm{O}\left({ }^{3} \mathrm{P}\right) / \mathrm{OH}$ flux ratio to a constant value.

In the first step, we fixed $\Phi_{0}(\mathrm{OH})$ at the value required to match the observed $\mathrm{CO}_{2}$ mole fraction of $1.5 \times 10^{-8}$ at $100-200 \mathrm{~km}$ in a steady-state situation. This $\Phi_{0}(\mathrm{OH})$ flux depends slightly on the photochemical network, being $5.1 \times$ $10^{6} \mathrm{~cm}^{-2} \mathrm{~s}^{-1}$ for $\mathrm{H} 08$ and $5.3 \times 10^{6} \mathrm{~cm}^{-2} \mathrm{~s}^{-1}$ for L14. These values are 16-20 times larger than the steady-state flux needed to match the $\mathrm{H}_{2} \mathrm{O}$ profile of Moreno et al. (2012) and 4-5.5 times larger than that required to match the $\mathrm{H}_{2} \mathrm{O}$ profile of Cottini et al. (2012). In the middle/upper atmosphere (say above $300 \mathrm{~km}$ ), the lifetime of $\mathrm{H}_{2} \mathrm{O}$ is short, so that the $\mathrm{H}_{2} \mathrm{O}$ mole fraction reacts to the "instantaneous" flux. This essentially constrains the flux to have declined by the above factors, which implies $t_{0} / \tau=2.9-3.2$ if the water targeted profile is $S_{a}$ in Moreno et al. (2012) and $t_{0} / \tau=1.5-1.8$ if the $\mathrm{H}_{2} \mathrm{O}$ abundance to be reproduced is from Cassini/CIRS data (Cottini et al. 2012). The value of $\tau$ (and hence $t_{0}$ ) remains to be adjusted. However, the $\mathrm{CO}_{2}$ abundance, which reflects the input flux that is "smoothed" over $300 \mathrm{yr}$, and the profile of $\mathrm{H}_{2} \mathrm{O}$ below $300-400 \mathrm{~km}$, tend to provide contradictory constraints. Short values of $\tau$ and $t_{0}$ are favored by $\mathrm{CO}_{2}$, while the steep $\mathrm{H}_{2} \mathrm{O}$ slope (i.e., the absence of a "kink" near $150 \mathrm{~km}$ ) would rather point to long values of $\tau$ and $t_{0}$. Figure 4 shows the profiles of $\mathrm{H}_{2} \mathrm{O}$ and $\mathrm{CO}_{2}$ for various $\left(\tau, t_{0}\right)$ combinations aimed at reproducing:

- (left panel): $\mathrm{H}_{2} \mathrm{O}$ from Herschel (Moreno et al. 2012) and $\mathrm{CO}_{2}$ from Cassini/CIRS observations (de Kok et al. 2007), and

- (right panel): $\mathrm{H}_{2} \mathrm{O}$ and $\mathrm{CO}_{2}$ from Cassini/CIRS observations (Cottini et al. 2012; de Kok et al. 2007).
In the first case (target $\mathrm{H}_{2} \mathrm{O}$ profile $=S_{a}$ from Moreno et al. (2012)), the $\left(\tau=30 \mathrm{yr}, t_{0}=96 \mathrm{yr}\right)$ combination permits to reproduce a $\mathrm{CO}_{2}$ profile that closely agrees with its observed value, but the $\mathrm{H}_{2} \mathrm{O}$ profile shows a marked local maximum and an abundance that is too large below $250 \mathrm{~km}$. Conversely, for $\left(\tau=1000 \mathrm{yr}, t_{0}=3100 \mathrm{yr}\right)$, the $\mathrm{H}_{2} \mathrm{O}$ profile is adequate, but $\mathrm{CO}_{2}$ is underabundant by a factor of 10 . Intermediate sets of parameters, such as $\left(\tau=100 \mathrm{yr}, t_{0}=300 \mathrm{yr}\right)$ or $(\tau=300 \mathrm{yr}$, $t_{0}=950 \mathrm{yr}$ ), produce unsatisfactory compromises with a poor fit for both species.

The same general conclusion can be seen in the right panel of Fig. 4, where the target $\mathrm{H}_{2} \mathrm{O}$ profile is now taken from Cottini et al. (2012). For $\left(\tau=30 \mathrm{yr}, t_{0}=55 \mathrm{yr}\right)$, the $\mathrm{CO}_{2}$ stratospheric value is close to the measurements, but the water profile sharply overestimates the $\mathrm{H}_{2} \mathrm{O}$ mixing ratio near $125 \mathrm{~km}$. For $\left(\tau=300 \mathrm{yr}, t_{0}=550 \mathrm{yr}\right), \mathrm{H}_{2} \mathrm{O}$ is brought into agreement with Cassini/CIRS results, but $\mathrm{CO}_{2}$ is considerably below observations.

As can be seen on the right panel of Fig. 4, the models tuned to match the $\mathrm{H}_{2} \mathrm{O}$ abundance somewhat overestimate the upper limits $\left(2.8 \times 10^{-6}\right.$ up to $3.9 \times 10^{-6}$ in the $1025-1151 \mathrm{~km}$ region) from INMS (Cui et al. 2009). A similar problem was encountered by Dobrijevic et al. (2014) for an Enceladus source. We note, however, that Cui et al. (2009) report actual detections of $\mathrm{H}_{2} \mathrm{O}$ on several inbound spectr with $\mathrm{H}_{2} \mathrm{O}$ mixing ratios in the range $(0.4-3.4) \times 10^{-5}$ with a mean value of $1.2 \times 10^{-5}$. These mixing ratios would then be consistent with model predictions, so the resolution of this issue must await a clarification of the constraints from INMS. At any rate, we note that the $\mathrm{H}_{2} \mathrm{O}$ thermospheric abundance is sensitive to the precise $\mathrm{OH}$ vs. $\mathrm{H}_{2} \mathrm{O}$ and vertical deposition profile and might also be affected by reactions (not considered here) that couple the $\mathrm{O}$ and $\mathrm{N}$ chemistry. In contrast, these effects do not affect the $\mathrm{H}_{2} \mathrm{O}$ and $\mathrm{CO}_{2}$ stratospheric abundances.

The above models assumed an initial $\Phi_{0}(\mathrm{OH})$ equal to the steady-state value needed to fit the $\mathrm{CO}_{2}$ abundance. We explored alternative models with a higher value for $\Phi_{0}(\mathrm{OH})$. Specifically 

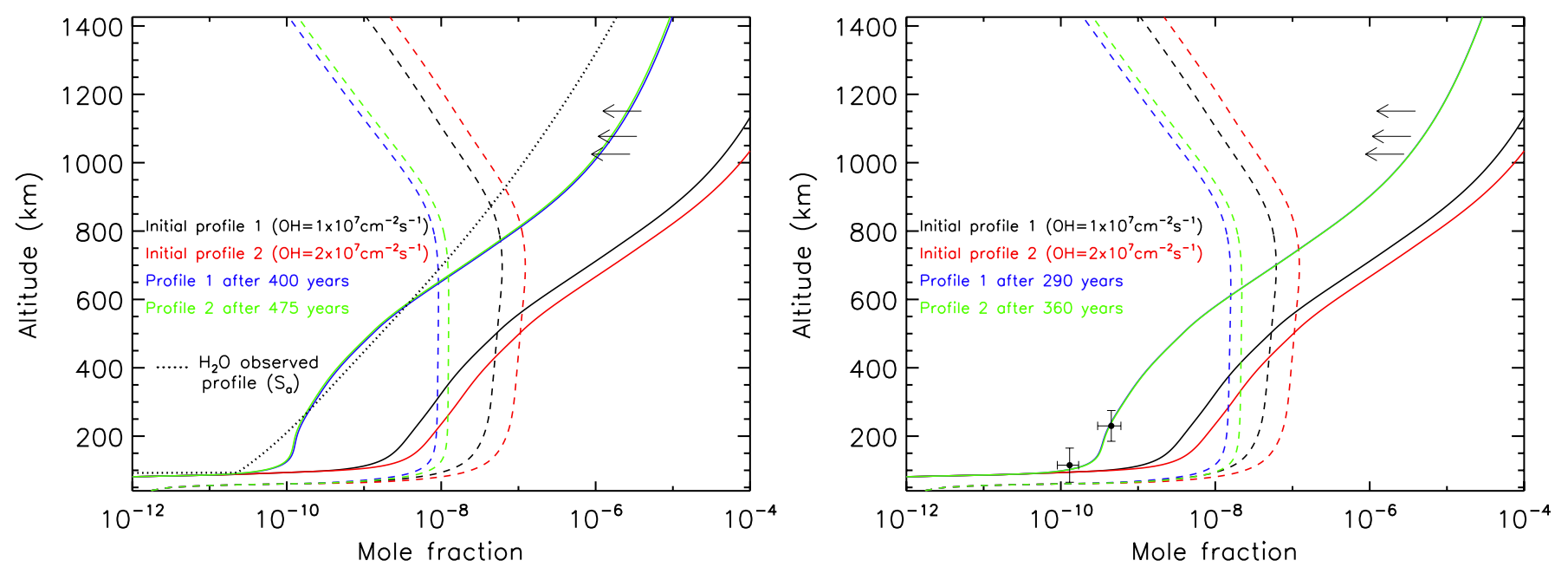

Fig. 5. $\mathrm{H}_{2} \mathrm{O}$ (solid lines) and $\mathrm{CO}_{2}$ (dashed lines) profiles in a time-dependent Enceladus source model (H08 chemistry) compared to the observed profile of $\mathrm{H}_{2} \mathrm{O}$ from (i) left panel: Herschel ( $S_{a}$ profile from Moreno et al. (2012); and (ii) right panel: Cassini/CIRS (Cottini et al. 2012) . Two initial conditions with different and enhanced $\mathrm{OH}$ input fluxes $\left(1.0 \times 10^{7}\right.$ in black lines and $2.0 \times 10^{7} \mathrm{~cm}^{-2} \mathrm{~s}^{-1}$ in red lines) are considered. Evolution times are adjusted so that the $\mathrm{H}_{2} \mathrm{O}$ mole fraction above $300 \mathrm{~km}$ matches observations in the case of Herschel data and at $230 \mathrm{~km}$ in the case of Cassini/CIRS. The resulting (i.e., after $t_{0}$ yr of evolution) $\mathrm{H}_{2} \mathrm{O}$ and $\mathrm{CO}_{2}$ profiles are plotted with blue and green lines for the initial profiles 1 and 2 , respectively (see text for more details). Upper limits on $\mathrm{H}_{2} \mathrm{O}$ thermospheric abundance by Cui et al. (2009) are also shown as arrows.

Table 5. Evolution time $t_{0}$ required to match the Herschel or Cassini/CIRS $\mathrm{H}_{2} \mathrm{O}$ profiles for both chemical schemes (H08 or L14).

\begin{tabular}{lcccc}
\hline \hline $\begin{array}{l}\Phi_{0}(\mathrm{OH}) \\
\left(\mathrm{cm}^{-2} \mathrm{~s}^{-1}\right)\end{array}$ & \multicolumn{2}{c}{ H08 chemical scheme } & \multicolumn{2}{c}{ L14 chemical scheme } \\
\hline & Herschel $^{a}$ & Cassini/CIRS & Herschel $^{a}$ & Cassini/CIRS \\
$1.0 \times 10^{7}$ & 400 & 290 & 375 & 260 \\
$2.0 \times 10^{7}$ & 475 & 360 & 450 & 330 \\
\hline
\end{tabular}

Notes. The time constant of the flux decline is $\tau=100$ years. ${ }^{(a)}$ Poor fit.

with the H08 chemical scheme, we considered two cases with initial fluxes of $\Phi_{0}(\mathrm{OH})=1.0 \times 10^{7}$ and $2.0 \times 10^{7} \mathrm{~cm}^{-2} \mathrm{~s}^{-1}$, respectively, that then declined with a time constant $\tau=100 \mathrm{yr}$. The evolution time $t_{0}$ needed to match the $\mathrm{H}_{2} \mathrm{O}$ Herschel abundance above $300 \mathrm{~km}$ altitude is $400 \mathrm{yr}$ and $475 \mathrm{yr}$ for the two cases, respectively. As shown in Fig. 5 (left panel), this scenario maintains larger $\mathrm{CO}_{2}$ values compared to the $\tau=100 \mathrm{yr}$ case shown in Fig. 4 (which had $t_{0}=300 \mathrm{yr}$ and $\Phi_{0}(\mathrm{OH})=$ $\left.5.1 \times 10^{6} \mathrm{~cm}^{-2} \mathrm{~s}^{-1}\right)$. The $\Phi_{0}(\mathrm{OH})=2.0 \times 10^{7} \mathrm{~cm}^{-2} \mathrm{~s}^{-1}$ case yields $\mathrm{CO}_{2}$ abundances that are essentially consistent with the observed $\sim 1.5 \times 10^{-8}$ value at $100-200 \mathrm{~km}$. However, the corresponding $\mathrm{H}_{2} \mathrm{O}$ profile still shows some "kink" below $200 \mathrm{~km}$. Direct comparison of synthetic spectra with data from Moreno et al. (2012) indicates that it still overpredicts the PACS lines (which probe the $90-150 \mathrm{~km}$ range) by $\sim 50 \%$ while the $\mathrm{H}_{2} \mathrm{O}$ model correctly fits the HIFI observations.

On the other hand, the same approach provides a satisfactory match to the Cassini/CIRS $\mathrm{H}_{2} \mathrm{O}$ measurements at 115 and $230 \mathrm{~km}$. Continuing with the same chemical scheme, initial $\Phi_{0}(\mathrm{OH})$ fluxes, and $\tau=100 \mathrm{yr}$, we find that the Cottini et al. (2012) $\mathrm{H}_{2} \mathrm{O}$ profile can be reproduced with $t_{0}=290 \mathrm{yr}$ for $\Phi_{0}(\mathrm{OH})=1.0 \times 10^{7} \mathrm{~cm}^{-2} \mathrm{~s}^{-1}$ and $t_{0}=360 \mathrm{yr}$ for $\Phi_{0}(\mathrm{OH})=$ $2.0 \times 10^{7} \mathrm{~cm}^{-2} \mathrm{~s}^{-1}$ (see Fig. 5, right panel). In both cases, the resulting $\mathrm{CO}_{2}$ stratospheric profile agrees well with observations.

We performed the same exercise by using the alternate chemical network (L14). Keeping the characteristic time of the flux decline at $\tau=100$ years, Table 5 summarizes the required values of the evolution time $t_{0}$ for the different cases. Similar behaviors are obtained with the two sets of chemistry. We conclude that this family of solutions is not satisfactory if the targeted water profile is the one retrieved from Herschel data, whereas a more successful fit of Cassini/CIRS water and carbon dioxide is obtained by assuming considerably $\mathrm{OH}$ higher fluxes some centuries ago.

\subsection{Loss to the haze}

Moreno et al. (2012) speculated that the $\mathrm{H}_{2} \mathrm{O}$ profile could be affected by an additional non-gaseous chemical loss, which can be a loss to the haze, as it seems to the case for HCN (McKay 1996; Lara et al. 1999; Vinatier et al. 2007). Moreno et al. (2012) found that adding a loss term in the form of $L=k\left[\mathrm{H}_{2} \mathrm{O}\right]^{1.75} \mathrm{~cm}^{-3} \mathrm{~s}^{-1}$ restricted to altitudes above $220 \mathrm{~km}$ would bring the model to the calculated $\mathrm{H}_{2} \mathrm{O}$ profile in agreement with the Herschel observations. However, they discarded this option because it does not help reconcile in itself the $\mathrm{H}_{2} \mathrm{O}$ and $\mathrm{CO}_{2}$ profiles in the steady-state scenario considered in Moreno et al. (2012).

Nonetheless, in this time-dependent scenario, a loss to the haze potentially reduces the $\mathrm{H}_{2} \mathrm{O}$ mole fraction in the lower stratosphere, as eliminates the $\mathrm{H}_{2} \mathrm{O}$ "kink" near $150 \mathrm{~km}$ and recoves an $\mathrm{H}_{2} \mathrm{O}$ profile in light with the Herschel observations. To illustrate this, here we come back to the short evolution case of Fig. 4 (left panel) (having $\Phi_{0}(\mathrm{OH})=5.1 \times 10^{6} \mathrm{~cm}^{-2} \mathrm{~s}^{-1}$, $\tau=30 \mathrm{yr}, t_{0}=96 \mathrm{yr}$ ), add a loss term of $\mathrm{H}_{2} \mathrm{O}$ to the haze in the form $L=k\left[\mathrm{H}_{2} \mathrm{O}\right]^{\beta} \mathrm{cm}^{-3} \mathrm{~s}^{-1}$ at $z>300 \mathrm{~km}$, which decreases with a $-100 \mathrm{~km}$ scale height below $300 \mathrm{~km}$. In a nominal case, we adopt $\beta=1.75$ by analogy to results of HCN (Lara et al. 1999), 
Table 6. Models with $\mathrm{H}_{2} \mathrm{O}$ loss to the haze.

\begin{tabular}{|c|c|c|c|c|c|c|}
\hline $\begin{array}{l}\Phi_{0}(\mathrm{OH}) \\
\left(\mathrm{cm}^{-2} \mathrm{~s}^{-1}\right) \\
\end{array}$ & $\begin{array}{c}\text { Chemical } \\
\text { network }\end{array}$ & $\begin{array}{l}\text { Target } \mathrm{H}_{2} \mathrm{O} \\
\text { profile } \\
\end{array}$ & $\begin{array}{l}\left(t_{0}, \tau\right) \\
(\text { year })\end{array}$ & $(k, \beta)$ & $\begin{array}{l}\mathrm{CO}_{2} \text { mixing ratio } \\
\text { at } 150 \mathrm{~km} \\
\end{array}$ & $\begin{array}{l}\mathrm{H}_{2} \mathrm{O} \text { integrated loss to the haze } \\
\left(\mathrm{cm}^{-2} \mathrm{~s}^{-1}\right)\end{array}$ \\
\hline $5.1 \times 10^{6}$ & H08 & $\begin{array}{c}\text { Herschel } \\
\text { Cassini/CIRS }\end{array}$ & $\begin{array}{l}(96,30) \\
(55,30)\end{array}$ & $\begin{array}{l}\left(5.0 \times 10^{-16}, 2\right) \\
\left(2.0 \times 10^{-14}, 1.75\right) \\
\left(1.5 \times 10^{-16}, 2\right) \\
\left(1.0 \times 10^{-14}, 1.75\right)\end{array}$ & $\begin{array}{l}9.3 \times 10^{-9} \\
9.2 \times 10^{-9} \\
1.2 \times 10^{-8} \\
1.2 \times 10^{-8}\end{array}$ & $\begin{array}{l}5.9 \times 10^{5} \\
6.5 \times 10^{5} \\
2.2 \times 10^{5} \\
2.5 \times 10^{5}\end{array}$ \\
\hline $5.3 \times 10^{6}$ & L14 & $\begin{array}{c}\text { Herschel } \\
\text { Cassini/CIRS }\end{array}$ & $\begin{array}{l}(87,30) \\
(45,30)\end{array}$ & $\begin{array}{l}\left(5.0 \times 10^{-16}, 2\right) \\
\left(2.0 \times 10^{-14}, 1.75\right) \\
\left(1.5 \times 10^{-16}, 2\right) \\
\left(1.0 \times 10^{-14}, 1.75\right)\end{array}$ & $\begin{array}{l}9.9 \times 10^{-9} \\
9.8 \times 10^{-9} \\
1.2 \times 10^{-8} \\
1.2 \times 10^{-8}\end{array}$ & $\begin{array}{l}6.1 \times 10^{5} \\
6.8 \times 10^{5} \\
2.5 \times 10^{5} \\
2.8 \times 10^{5}\end{array}$ \\
\hline
\end{tabular}

but solutions with different forms are possible. The red circles in the left panel of Fig. 4 show the resulting $\mathrm{H}_{2} \mathrm{O}$ profile obtained with $k=2 \times 10^{-14}$. This profile fully agrees with the empirical $S_{a}$ profile of Moreno et al. (2012). Alternate functional dependences of $L$ are possible; for example, $L=k^{\prime}\left[\mathrm{H}_{2} \mathrm{O}\right]^{2} \mathrm{~cm}^{-3} \mathrm{~s}^{-1}$ with $k^{\prime}=5 \times 10^{-16}$ at $z>300 \mathrm{~km}$ and similarly decreases below this altitude produces an identical fit. In these models, the total $\mathrm{H}_{2} \mathrm{O}$ loss to the haze is $\sim 6 \times 10^{5} \mathrm{~cm}^{-2} \mathrm{~s}^{-1}$.

For completeness, this study has been extended to the case of the $\mathrm{H}_{2} \mathrm{O}$ Cassini/CIRS profile and also considers the two chemical schemes. Table 6 shows results of the $(k, \beta)$ parameters and the total $\mathrm{H}_{2} \mathrm{O}$ loss to the haze for the different cases.

As a conclusion, including a loss to the haze term in combination on with a time variable flux brings the modeled $\mathrm{H}_{2} \mathrm{O}$ profile in agreement with available observations (Cottini et al. 2012; Moreno et al. 2012) for both of the chemical schemes used here, which maintains $\mathrm{CO}_{2}$ stratospheric profiles in broad agreement with Cassini/CIRS data (de Kok et al. 2007).

\section{Comet impact scenario}

In this section, we investigate another alternative for the high $\mathrm{CO}_{2} / \mathrm{H}_{2} \mathrm{O}$ ratio in Titan's atmosphere: namely, the $\mathrm{CO}_{2}$ that has built up from a relatively recent cometary impact. As shown from the Shoemaker-Levy 9 impacts on Jupiter in 1994, cometary impacts can deliver oxygen compounds to planets. In the Jupiter/SL9 case, shock chemistry at plume re-entry has produced $\mathrm{CO}$ and $\mathrm{H}_{2} \mathrm{O}$ near the 0.1 mbar level (Lellouch et al. 1997, 2002), and both species have since then slowly diffused vertically and horizontally (see Moreno et al. 2003; Cavalié et al. 2013, and references therein). Furthermore, while CO is chemically stable, any newly injected $\mathrm{H}_{2} \mathrm{O}$ is progressively photolysed to $\mathrm{OH}$ and converted to $\mathrm{CO}_{2}$ by reaction with $\mathrm{CO}$. The gas $\mathrm{CO}_{2}$ was observed in 1997 in Jupiter (Lellouch et al. 2002) with a north-south assymetry characteristic of a SL9-derived product (Lellouch et al. 2002). Based on coupled photochemicalhorizontal transport modeling, the amount of carbon dioxide and latitudinal distribution could be explained if the material produced by the impacts has a $\mathrm{H}_{2} \mathrm{O} / \mathrm{CO}$ ratio of about 0.11 per volume. In Jupiter's atmosphere, the model further predicted that $\mathrm{CO}_{2}$ produced in this manner would build up for about $50 \mathrm{yr}$ after the impacts and then begin to decline due to its own photolysis. Comet impacts are also invoked to explain the abundance of CO in Neptune's stratosphere (Lellouch et al. 2005; Hesman et al. 2007) and possibly Saturn's (Cavalié et al. 2010).

We first examine the scenario for Titan in terms of the involved amounts. The $\mathrm{CO}_{2}$ column density in Titan's atmosphere is $3.6 \times 10^{16} \mathrm{~cm}^{-2}$ which corresponds to $3.0 \times 10^{34}$ molecules referred to the surface. Assuming full conversion of $\mathrm{H}_{2} \mathrm{O}$ to $\mathrm{CO}_{2}$ and using an initial $\mathrm{H}_{2} \mathrm{O} / \mathrm{CO}$ ratio of 0.1 , this implies that the hypothetical comet delivered $3.0 \times 10^{34} \mathrm{H}_{2} \mathrm{O}$ and $3.0 \times 10^{35} \mathrm{CO}$ molecules (i.e, a CO mass of $1.4 \times 10^{13} \mathrm{~g}$ ). Converting this $\mathrm{CO}$ mass into a comet size requires an assumption of the "CO yield" and the comet density. We use a 50\% yield (Lellouch et al. 1997 , 2005) and a $0.5 \mathrm{~g} \mathrm{~cm}^{-3}$ mass density. This gives a minimum $D=0.475 \mathrm{~km}$ comet diameter.

We then consider the time evolution of a "pure" cometary case, by first considering the constraints from the $\mathrm{H}_{2} \mathrm{O}$ Herschel profile. The $\mathrm{CO}$ and $\mathrm{H}_{2} \mathrm{O}$ mole fractions are initialized as $q_{\mathrm{CO}}$ and $q_{\mathrm{H}_{2} \mathrm{O}}$, which are taken as uniform above $300 \mathrm{~km}(0.1 \mathrm{mbar})$ and zero below this altitude. These values are considered as constant over the Titan globe. Thus the model is not initialized at comet impact, but a few years after when the species have been mixed horizontally and vertically above the $300 \mathrm{~km}$ range $\left(q=q_{\mathrm{CO}}\right)$. We impose $q_{\mathrm{CO}}=10 \times q_{\mathrm{H}_{2} \mathrm{O}}$, and these values are adjusted until the $\mathrm{CO}_{2}$ mole fraction matches the observations after some evolution time $t_{\text {evol }}$. Figure 6 (left panel) shows two cases (both of which consider the H08 chemical network): (1) $q_{\mathrm{CO}}=6 \times 10^{-5}, t_{\mathrm{evol}}=300 \mathrm{yr}$; and (2) $q_{\mathrm{CO}}=6 \times 10^{-4}$, $t_{\text {evol }}=700 \mathrm{yr}$. These two cases correspond to the deposition of $1.2 \times 10^{36}$ and $1.2 \times 10^{37} \mathrm{CO}$ molecules implying a cometary diameter of 0.7 and $1.5 \mathrm{~km}$ ("small" and "large"), respectively, under the above assumptions on density and $\mathrm{CO}$ yield. Both cases produce roughly the same amount of $\mathrm{CO}_{2}$; in contrast, a significantly larger amount of $\mathrm{H}_{2} \mathrm{O}$ is present in the first case, although this amount of water is importantly below the Herschel observations in both cases. Case (1) represents the maximum amount of cometary $\mathrm{H}_{2} \mathrm{O}$ that can be accomodated by the observed Herschel $\mathrm{H}_{2} \mathrm{O}$ profile. This implies that the comet impact occured at least $300 \mathrm{yr}$ ago with a minimum comet diameter of $700 \mathrm{~m}$. Older impacts are possible but require larger impactor sizes to maintain the same amount of $\mathrm{CO}_{2}$.

The right panel of Fig. 6 shows similar models but are tailored to the Cassini/CIRS $\mathrm{H}_{2} \mathrm{O}$ profile. The "large" comet case is unchanged, but the "small" comet case has values of $q_{\mathrm{CO}}=$ $3 \times 10^{-5}, t_{\mathrm{evol}}=225 \mathrm{yr}$. Indeed, the larger stratospheric abundance in the Cassini/CIRS $\mathrm{H}_{2} \mathrm{O}$ profile can accomodate a larger residual cometary $\mathrm{H}_{2} \mathrm{O}$ than the Herschel profile. This can be achieved by invoking a smaller and more recent impact (leading to the same $\mathrm{CO}_{2}$ amount but a larger $\mathrm{H}_{2} \mathrm{O} / \mathrm{CO}_{2}$ ratio after evolution). As it is clear in the right panel of Fig. 6, this case is close to the maximum value of cometary $\mathrm{H}_{2} \mathrm{O}$ that can be tolerated by the observed Cassini/CIRS $\mathrm{H}_{2} \mathrm{O}$ profile. This means that if the Cassini/CIRS $\mathrm{H}_{2} \mathrm{O}$ profile is valid, the impact age could be as young as 225 years with the minimum size of $550 \mathrm{~m}$. Again, older and larger impacts are possible.

We can also combine one of the above models with steadystate production of the oxygen species. This scenario thus 

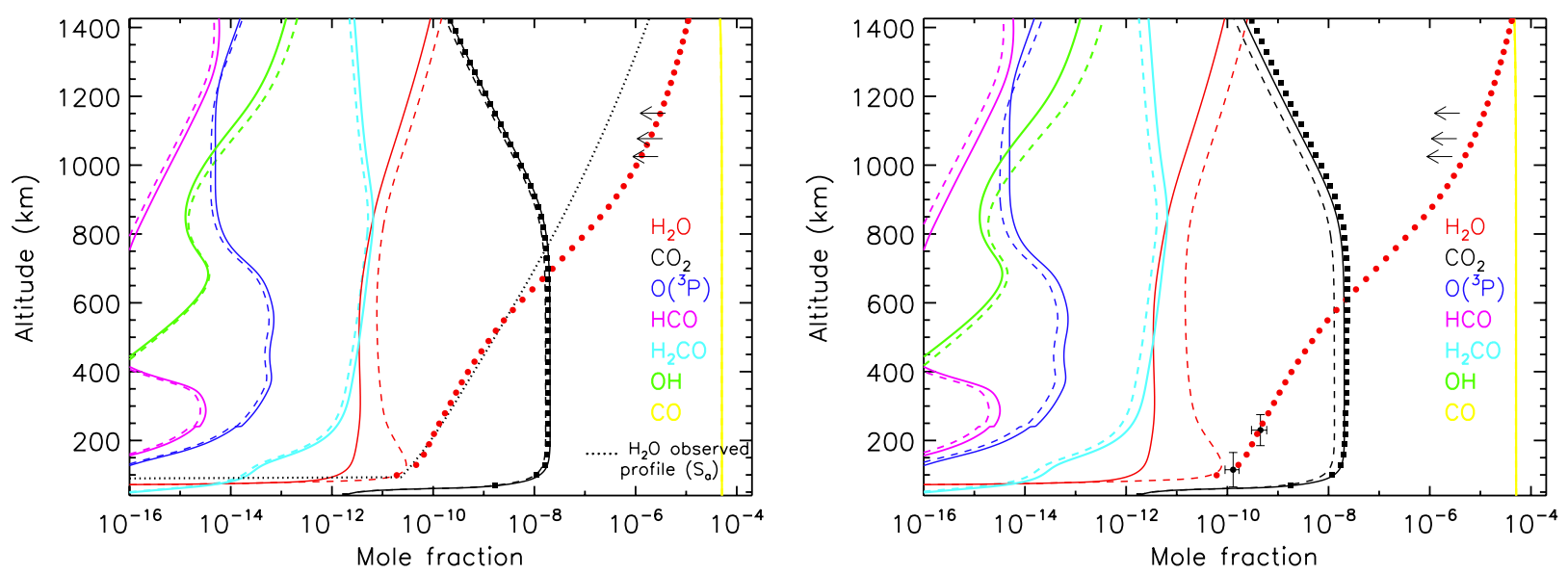

Fig. 6. Evolution of oxygen species after a cometary impact. Initial conditions correspond to deposition of $\mathrm{CO}$ and $\mathrm{H}_{2} \mathrm{O}$ with uniform mixing ratios (with $q_{\mathrm{CO}}=10 q_{\mathrm{H}_{2} \mathrm{O}}$ ) above $300 \mathrm{~km}$. Left panel: models suited to the Herschel $\mathrm{H}_{2} \mathrm{O}$ profile ( $S_{a}$ from Moreno et al. (2012)). Dashed lines: "small comet" (initial $q_{\mathrm{CO}}=6 \times 10^{-5}$ ), evolution time $t_{\mathrm{evol}}=300 \mathrm{yr}$. Solid lines: "large comet" (initial $q_{\mathrm{CO}}=6 \times 10^{-4}$ ), evolution time $t_{\mathrm{evol}}=700 \mathrm{yr}$. The red circles and black squares show the $\mathrm{H}_{2} \mathrm{O}$ and $\mathrm{CO}_{2}$ for the combination of the "large comet" case with a steady $\mathrm{OH}$ influx of $2.4 \times 10^{5} \mathrm{~cm}^{-2} \mathrm{~s}^{-1}$. Right panel: models suited to the Cassini/CIRS $\mathrm{H}_{2} \mathrm{O}$ profile Cottini et al. (2012). Dashed lines: "smaller comet" (initial $q_{\mathrm{CO}}=3 \times 10^{-5}$ ), evolution time $t_{\text {evol }}=225$ yr. Solid lines: "large comet" (initial $q_{\mathrm{CO}}=6 \times 10^{-4}$ ), evolution time $t_{\text {evol }}=700 \mathrm{yr}$. The red circles and black squares show the $\mathrm{H}_{2} \mathrm{O}$ and $\mathrm{CO}_{2}$ for the combination of the "large comet" case with a steady $\mathrm{OH}$ influx of $9.0 \times 10^{5} \mathrm{~cm}^{-2} \mathrm{~s}^{-1}$. Upper limits on $\mathrm{H}_{2} \mathrm{O}$ thermospheric abundance by Cui et al. (2009) are also shown as arrows.

depicts the current abundance of oxygen species as a result from the combination of a steady (Enceladus or micrometeorite) source and the evolution of a cometary "spike". The steady source is primarily responsible for the $\mathrm{H}_{2} \mathrm{O}$ abundance, while $\mathrm{CO}_{2}$ is mostly the result of the comet impact. The dotted lines in Fig. 6 show the combination of the "large comet" above case with an Enceladus source (with a steady $\mathrm{OH}$ source rate of $2.4 \times 10^{5} \mathrm{~cm}^{-2} \mathrm{~s}^{-1}$ in the left panel and $9.0 \times 10^{5} \mathrm{~cm}^{-2} \mathrm{~s}^{-1}$ in the right panel). The resulting $\mathrm{H}_{2} \mathrm{O}$ profiles after $700 \mathrm{yr}$ evolution agree with Herschel and Cassini/CIRS observations, respectively, and the $\mathrm{CO}_{2}$ profile is also fit.

The use of the alternate (L14) oxygen chemical scheme does not noticeably influence the results above. Matching the observations for the same model assumptions in terms of comet size and evolution time only requires a slight $(\leq 10 \%)$ increase of the $\Phi_{\mathrm{OH}}$ that is provided by the steady Enceladus source. This is to be expected from Table 4, which shows the L14 oxygen chemical scheme to be slightly less efficient in producing atmospheric water.

While these models “technically' work, their main difficulty is in the plausibility of a recent impact at Titan. Zahnle et al. (2003) find that the number of impacts on Jupiter by $1.5 \mathrm{~km}$ or larger ecliptic comets is typically 0.005 peryear. They further provide probabilities for ecliptic comet impacts relative to Jupiter for all outer planets and satellites. For Titan, this relative probability is given as $5.4 \times 10^{-5}$, which means that Titan is hit by a $D>1.5 \mathrm{~km}$ comet every $\sim 4$ million years on average. The size distribution of the cumulative impact rate is not very steep (slope parameter $b=1-1.7$ in this size range, according to Zahnle et al. 2003), which means that the occurrence of a $0.5 \mathrm{~km}$ comet impact at Titan is only 3-6 times larger. We are still left with typical impact times of $\sim 1$ million years, which is probably fatal for this scenario.

\section{Conclusions}

We have explored Titan oxygen photochemistry by using a timevariable photochemical model and considering two variants for the oxygen chemical schemes. We find that the effective lifetime of $\mathrm{H}_{2} \mathrm{O}$ in Titan's atmosphere exceeds $10 \mathrm{yr}$ below $200 \mathrm{~km}$, which is only a factor of six shorter than that of $\mathrm{CO}_{2}$ when the column densities are averaged. As a consequence, solving the inconsistency between the $\mathrm{OH} / \mathrm{H}_{2} \mathrm{O}$ fluxes required matching the observed $\mathrm{H}_{2} \mathrm{O}$ and $\mathrm{CO}_{2}$ amounts, which is not straightforward and depends on the magnitude of the flux discrepancy. We find that if the Cottini et al. (2012) measurements are representative of Titan's true $\mathrm{H}_{2} \mathrm{O}$ profile, the factor about five in the discrepancy in flux can be solved by invoking a decrease by a factor of ten in the $\mathrm{OH} / \mathrm{H}_{2} \mathrm{O}$ flux (i.e., of Enceladus' plume activity) over the last $\sim 300$ years. While the past activity of Enceladus is unconstrained, the fact that active plumes are currently not emitted along entire tiger stripes fractures and that thermal anomalies are not limited to fractures leaves open the possibility of a more extended and intense activity. If on the other hand, Titan's water is even less abundant by about another factor of four as found by Moreno et al. (2012), we find that the time-dependent flux scenario is not in itself able to solve the problem and that another loss term for $\mathrm{H}_{2} \mathrm{O}$, such as a loss to the haze, has to be invoked.

Acknowledgements. This research has been supported by the Spanish Ministerio de Ciencia e Innovación under contract AyA 2009-08011 and Ministerio de Economía y Competitividad under contract AyA 2012-32237. We thank Ralph D. Lorenz for suggesting the comet impact scenario to us.

\section{References}

Adachi, H., Basco, H., \& James, D. 1981, Int. J. Chem. Kinet., 13, 1251 Adamson, J., Farhat, S., Morter, C., et al. 1994, J. Phys. Chem., 98, 5665 Ashfold, M., Fullstone, M., Hancock, G., \& Ketley, G. 1981, Chem. Phys., 55, 245

Atkinson, R., Baulch, D. L., Cox, R. A., et al. 2004, Atmos. Chem. Phys., 4, 1461

Atkinson, R., Baulch, D. L., Cox, R. A., et al. 2006, Atmos. Chem. Phys., 6, 3625

Balucani, N., Leonori, F., \& Casavecchia, P. 2012, Energy, 43, 47

Bartels, M., Edelbüttel-Einhaus, J., \& Hoyermann, K. 1991, Symp. Int. Combust. Proc., 23, 131

Baulch, D. L., Cobos, C. J., Cox, R. A., et al. 1992, J. Phys. Chem. Ref. Data, 21,411 
Baulch, D. L., Cobos, C. J., Cox, R. A., et al. 1994, J. Phys. Chem. Ref. Data, 23,847

Baulch, D., Bowman, C., Cobos, C., et al. 2005, J. Phys. Chem. Ref. Data, 34, 757

Bergeat, A., Moisan, S., Méreau, R., \& Loison, J.-C. 2009, Chem. Phys. Lett., 480, 21

Berman, M., Fleming, J., Harvey, A., \& Lin, M. 1982, Proc. Combustion Institute, 19, 73

Blitz, M., Pesa, M., Pilling, M., \& Seakins, P. 1999, J. Phys. Chem. A, 103, 5699

Böhland, T., Temps, F., \& Wagner, H. G. 1984, Z. Electrochem., 88, 1222

Böhland, T., Temps, F., \& Wagner, H. G. 1985, Berichte der Bunsengesellschaft für physikalische Chemie, 89, 1013

Böhland, T., Temps, F., \& Wagner, H. 1988, Proc. Combustion Institute, 21, 841

Canosa, A., Sims, I. R., Travers, D., Smith, I. W. M., \& Rowe, B. R. 1997, A\&A, 323,644

Carl, S. A., Minh Thi Nguyen, H., Elsamra, R. M. I., Tho Nguyen, M., \& Peeters, J. 2005, J. Chem. Phys., 122

Cavalié, T., Hartogh, P., Billebaud, F., et al. 2010, A\&A, 510, A88

Cavalié, T., Feuchtgruber, H., Lellouch, E., et al. 2013, A\&A, 553, A21

Cody, R. J., Romani, P. N., Nesbitt, F. L., et al. 2003, J. Geophys. Res.: Planets, 108,5

Cottini, V., Nixon, C. A., Jennings, D. E., et al. 2012, Icarus, 220, 855

Coustenis, A., Salama, A., Lellouch, E., et al. 1998, A\&A, 336, L85

Cui, J., Yelle, R. V., Vuitton, V., et al. 2009, Icarus, 200, 581

Davidson, J., Schiff, H., Brown, T., \& Howard, C. J. 1978, J. Chem. Phys., 69 1216

Dóbó, S., Bórces, T., \& Szilágyi, I. 1991, J. Chem. Soc., Faraday Transactions, 87,2331

De Avillez Pereira, R., Baulch, D., Pilling, M., Robertson, S., \& Zeng, G. 1997, J. Phys. Chem. A, 101, 9681

de Kok, R., Irwin, P. G. J., Teanby, N. A., et al. 2007, Icarus, 186, 354

de La Haye, V., Waite, J. H., Johnson, R. E., et al. 2007, J. Geophys. Res., 112, 7309

Dobrijevic, M., Hébrard, E., Loison, J. C., \& Hickson, K. M. 2014, Icarus, 228, 324

Fahr, A., \& Laufer, A. 1995, J. Phys. Chem., 99, 262

Fahr, A., Laufer, A., Klein, R., \& Braun, W. 1991, J. Phys. Chem., 95, 3218

Feuchtgruber, H., Lellouch, E., de Graauw, T., et al. 1997, Nature, 389, 159

Fu, B., Han, Y.-C., Bowman, J., et al. 2012a, Proc. Nat. Acad. Sci. USA, 109, 9733

Fu, B., Han, Y.-C., Bowman, J., et al. 2012b, J. Chem. Phys., 137, 22A532

Fulchignoni, M., Ferri, F., Angrilli, F., et al. 2005, Nature, 438, 785

Fulle, D., \& Hippler, H. 1997, J. Chem. Phys., 106, 8691

Gurwell, M. A. 2004, ApJ, 616, L7

Hack, W., Hold, M., Hoyermann, K., Wehmeyer, J., \& Zeuch, T. 2005, Phys. Chem. Chem. Phys, 7, 1977

Hanning-Lee, M. A., \& Pilling, M. J. 1992, Int. J. Chem. Kinet., 24, 271

Harding, L., Klippenstein, S., Georgievskii, Y., et al. 2005, Proc. Combustion Institute, 30I, 985

Hassinen, E., Kalliorinne, K., \& Koskikallio, J. 1990, Int. J. Chem. Kinetics, 22

Hébrard, E., Dobrijevic, M., Loison, J. C., et al. 2013, A\&A, 552, A132

Heinemann, P., Hofmann-Sievert, R., \& Hoyermann, K. 1988, Proc. Combustion Institute, 21, 865

Hesman, B. E., Davis, G. R., Matthews, H. E., \& Orton, G. S. 2007, Icarus, 186, 342

Hickson, K., Caubet, P., \& Loison, J.-C. 2013, J. Phys. Chem. Lett., 4, 2843

Homann, K., \& Wellmann, C. 1983, Berichte der Bunsengesellschaft/Physical Chemistry Chemical Physics, 87, 609, 33

Hörst, S. M., Vuitton, V., \& Yelle, R. V. 2008, J. Geophys. Res. Planets, 113, 10006

Hoyermann, K., Loftfield, N., Sievert, R., \& Wagner, H. 1981, Proc. Combustion Institute, 18,831

Hoyermann, K., Olzmann, M., Seeba, J., \& Viskolcz, B. 1999, J. Phys. Chem. A, 103,5692
Jasper, A., Klippenstein, S., Harding, L., \& Ruscic, B. 2007, J. Phys. Chem. A, 111,3932

Klemm, R. B. 1979, J. Chem. Phys., 71, 1987

Knyazev, V., \& Slagle, I. 2001, J. Phys. Chem. A, 105, 3196

Koyano, I., Wauchop, T. S., \& Welge, K. H. 1975, J. Chem. Phys., 63, 110

Krasnoperov, L., Chesnokov, E., Stark, H., et al. 2005, Proc. Combustion Institute, 30 I, 935

Krasnopolsky, V. A. 2009, Icarus, 201, 226

Langford, A. O., Petek, H., \& Moore, C. B. 1983, J. Chem. Phys., 78, 6650

Lara, L. M., Lellouch, E., López-Moreno, J. J., \& Rodrigo, R. 1996, J. Geophys. Res., 101, 23261

Lara, L.-M., Lellouch, E., \& Shematovich, V. 1999, A\&A, 341, 312

Laufer, A., \& Fahr, A. 2004, Chem. Rev., 104, 2813

Laufer, A., Gardner, E., Kwok, T., \& Yung, Y. 1983, Icarus, 56, 560

Lavvas, P. P., Coustenis, A., \& Vardavas, I. M. 2008, Planet. Space Sci., 56, 27

Lellouch, E., Bézard, B., Moreno, R., et al. 1997, Planet. Space Sci., 45, 1203

Lellouch, E., Bézard, B., Moses, J. I., et al. 2002, Icarus, 159, 112

Lellouch, E., Moreno, R., \& Paubert, G. 2005, A\&A, 430, L37

McKay, C. P. 1996, Planet. Space Sci., 44, 741

Monks, P., Nesbitt, F., Payne, W., et al. 1995, J. Phys. Chem., 99, 17151

Moreno, R., Marten, A., Matthews, H. E., \& Biraud, Y. 2003, Planet. Space Sci., 51,591

Moreno, R., Lellouch, E., Lara, L. M., et al. 2012, Icarus, 221, 753

Moses, J., Bézard, B., Lellouch, E., et al. 2000, Icarus, 143, 244

Moses, J. I., Fouchet, T., Bézard, B., et al. 2005, J. Geophys. Res. Planets, 110, 8001

Murhpy, J., Vakhtin, A., \& Leone, S. 2003, Icarus, 163, 175

Nava, D. F., Mitchell, M. B., \& Stief, L. J. 1986, J. Geophys. Res., 91, 4585

Ohmori, K., Miyoshi, A., Matsui, H., \& Washida, N. 1990, J. Phys. Chem., 94, 3253

Okabe, H. 1978, Photochemistry of Small Molecules (New York: Wiley Interscience Publication)

Opansky, B., \& Leone, S. 1996a, J. Phys. Chem., 100, 4888

Opansky, B., \& Leone, S. 1996b, J. Phys. Chem., 100, 19904

Pereira, R., Baulch, D., Pilling, J., Robertson, S., \& Zheng, G. 1997, J. Phys. Chem. A, 101, 9681

Pitts, W. M., Pasternack, L., \& McDonald, J. 1982, Chem. Phys., 68, 417

Pratt, G. L., \& Wood, S. W. 1984, J. Chem. Soc., Faraday Trans. 1, 80, 3419

Sander, S. P., Friedl, R. R., Ravishankara, A. R., et al. 2006, NASA JPL Publication 06-2

Sander, S. P., Friedl, R. R., Ravishankara, A. R., et al. 2011, NASA JPL Publication 10-6

Sangwan, M., Chesnokov, E., \& Krasnoperov, L. 2012, J. Phys. Chem. A, 116, 8661

Schwanebeck, W., \& Warnatz, J. 1975, Ber. Bunsenges. Phys. Chem., 79, 530

Shepler, B., Yang, B., Dhilip Kumar, T., et al. 2007, A\&A, 475, L15

Tsang, W. 1991, J. Phys. Chem. Ref. Data, 20, 221

Tsang, W., \& Hampson, R. 1986, J. Phys. Chem. Ref. Data, 15, 1087

Tully, J. C. 1975, J. Chem. Phys., 62, 1893

Vakhtin, A., Heard, D., Smith, I., \& Leone, S. 2001, Chem. Phys. Lett., 348, 21

Vanlook, H., \& Peeters, J. 1995, J. Phys. Chem., 99

Vinatier, S., Bézard, B., Fouchet, T., et al. 2007, Icarus, 188, 120

Vinatier, S., Bézard, B., Nixon, C. A., et al. 2010, Icarus, 205, 559

Vinckier, C. 1979, J. Chem. Phys., 83

Wagner, A., \& Bowman, J. 1987, J. Phys. Chem., 91, 5314

Wagner, H. G., \& Zellner, R. 1972, Ber. Bunsen-Ges. Phys. Chem.

Wang, H., \& Frenklach, M. 1997, Combust. Flame, 110, 173

Wang, B., Hou, H., \& Gu, Y. 2000, J. Chem. Phys., 112, 8458

Wang, H. Y., Eyre, J. A., \& Dorfman, L. M. 1973, J. Chem. Phys., 59

Wilson, E. H., \& Atreya, S. K. 2004, J. Geophys. Res. Planets, 109, 6002

Yung, Y. L., Allen, M., \& Pinto, J. P. 1984, ApJS, 55, 465

Zabarnick, S., Fleming, J., \& Lin, M. 1988, Proc. Combustion Institute, 21, 713

Zahnle, K., Schenk, P., Levison, H., \& Dones, L. 2003, Icarus, 163, 263

Zhang, X., Zou, S., Harding, L., \& Bowman, J. 2004, J. Phys. Chem. A, 108, 8980

Zhu, R., Xu, Z., \& Lin, M. 2004, J. Chem. Phys., 120, 6566

Zwier, T., \& Allen, M. 1996, Icarus, 123, 578 
Table 1. Hydrocarbon reactions.

\begin{tabular}{|c|c|c|c|}
\hline & Reaction & Rate coefficient & Reference \\
\hline R1a & ${ }^{\mathrm{I}} \mathrm{CH}_{2}+\mathrm{H}_{2} \rightarrow \mathrm{CH}_{3}+\mathrm{H}$ & $9.24 \times 10^{-11}$ & Langford et al. (1983) \\
\hline $\mathrm{R} 1 \mathrm{~b}$ & ${ }^{1} \mathrm{CH}_{2}+\mathrm{H}_{2} \rightarrow{ }^{3} \mathrm{CH}_{2}+\mathrm{H}_{2}$ & $1.26 \times 10^{-11}$ & Langford et al. (1983) \\
\hline $\mathrm{R} 2$ & ${ }^{1} \mathrm{CH}_{2}+\mathrm{CH}_{4} \rightarrow \mathrm{CH}_{3}+\mathrm{CH}_{3}$ & $6.0 \times 10^{-11}$ & Böhland et al. (1985) \\
\hline R3 & $\mathrm{CH}+\mathrm{CH}_{4} \rightarrow \mathrm{C}_{2} \mathrm{H}_{4}+\mathrm{H}$ & $3.96 \times 10^{-8} T^{-1.04} \mathrm{e}^{-36.1 / T}$ & Canosa et al. (1997) \\
\hline $\mathrm{R} 4$ & $\mathrm{CH}+\mathrm{H}_{2}+\mathrm{M} \rightarrow \mathrm{CH}_{3}+\mathrm{M}$ & $\begin{array}{l}k_{0}=8.75 \times 10^{-31} \mathrm{e}^{524 / T} \\
k=83 \times 10^{-11}\end{array}$ & Moses et al. (2005) \\
\hline R5 & $\mathrm{H}+\mathrm{CH}_{3}+\mathrm{M} \rightarrow \mathrm{CH}_{4}+\mathrm{M}$ & $\begin{array}{l}k_{\infty}=8.3 \times 10 \\
k_{0}=1.7 \times 10^{-24} T^{-1.8} \\
k_{\infty}=3.5 \times 10^{-10}\end{array}$ & $\begin{array}{l}\text { Fulle \& Hippler (1997) } \\
\text { Baulch et al. (1994) }\end{array}$ \\
\hline R6 & $\mathrm{CH}_{3}+\mathrm{CH}_{3}+\mathrm{M} \rightarrow \mathrm{C}_{2} \mathrm{H}_{6}+\mathrm{M}$ & $\begin{array}{l}k_{0}=2.822 \times 10^{-3} T^{-8.749} \mathrm{e}^{-985.4 / T} \\
k_{\infty}=9.3132 \times 10^{-11} \mathrm{e}^{-1.519 \times 10^{-3} T}\end{array}$ & $\begin{array}{l}\text { Cody et al. (2003); } \\
\text { Lavvas et al. (2008) }\end{array}$ \\
\hline $\mathrm{R} 7$ & $\mathrm{H}+\mathrm{H}+\mathrm{M} \rightarrow \mathrm{H}_{2}+\mathrm{M}$ & $\begin{array}{l}k_{0}=1.5 \times 10^{-29} T^{-1.3} \\
k_{\infty}=1.0 \times 10^{-11}\end{array}$ & $\begin{array}{l}\text { Tsang \& Hampson (1986) } \\
\text { Lavvas et al. (2008) }\end{array}$ \\
\hline $\mathrm{R} 8$ & $\mathrm{H}+\mathrm{C}_{2} \mathrm{H}_{2}+\mathrm{M} \rightarrow \mathrm{C}_{2} \mathrm{H}_{3}+\mathrm{M}$ & $\begin{array}{l}k_{0}=2.6 \times 10^{-31} \\
k_{\infty}=3.8 \times 10^{-11} \mathrm{e}^{-1374 / T}\end{array}$ & Baulch et al. (1992) \\
\hline R9 & $\mathrm{H}+\mathrm{C}_{2} \mathrm{H}_{3} \rightarrow \mathrm{C}_{2} \mathrm{H}_{2}+\mathrm{H}_{2}$ & $3.30 \times 10^{-11}$ & Monks et al. (1995) \\
\hline R10 & $\mathrm{H}_{2}+\mathrm{C}_{2} \mathrm{H}_{3} \rightarrow \mathrm{C}_{2} \mathrm{H}_{4}+\mathrm{H}$ & $2.6 \times 10^{-13} \mathrm{e}^{-2646 / T}$ & Fahr \& Laufer (1995) \\
\hline $\mathrm{R} 11$ & $\mathrm{H}+\mathrm{C}_{2} \mathrm{H}_{4}+\mathrm{M} \rightarrow \mathrm{C}_{2} \mathrm{H}_{5}+\mathrm{M}$ & $\begin{array}{l}k_{0}=2.15 \times 10^{-29} T^{-2} \mathrm{e}^{-349 / T} \\
k_{\infty}=4.95 \times 10^{-11} \mathrm{e}^{-1051 / T}\end{array}$ & Baulch et al. (1994) \\
\hline R12 & $\mathrm{H}+\mathrm{C}_{2} \mathrm{H}_{5} \rightarrow \mathrm{CH}_{3}+\mathrm{CH}_{3}$ & $7.95 \times 10^{-11} \mathrm{e}^{-127 / T}$ & Pratt \& Wood (1984) \\
\hline $\mathrm{R} 13$ & ${ }^{3} \mathrm{CH}_{2}+\mathrm{H}+\mathrm{M} \rightarrow \mathrm{CH}_{3}+\mathrm{M}$ & $\begin{array}{l}k_{0}=3.4 \times 10^{-32} \mathrm{e}^{736 / T} \\
k_{\infty}=7.3 \times 10^{-12}\end{array}$ & Moses et al. (2000) \\
\hline R14 & ${ }^{3} \mathrm{CH}_{2}+\mathrm{CH}_{3} \rightarrow \mathrm{C}_{2} \mathrm{H}_{4}+\mathrm{H}$ & $7.0 \times 10^{-11}$ & Tsang \& Hampson (1986) \\
\hline $\mathrm{R} 15$ & ${ }^{3} \mathrm{CH}_{2}+\mathrm{C}_{2} \mathrm{H}_{2}+\mathrm{M} \rightarrow \mathrm{CH}_{3} \mathrm{C}_{2} \mathrm{H}+\mathrm{M}$ & $\begin{array}{l}k_{0}=6.0 \times 10^{-29} \mathrm{e}^{1680 / T} \\
k_{\infty}=2.0 \times 10^{-12} \mathrm{e}^{-3330 / T}\end{array}$ & Böhland et al. (1988) \\
\hline $\mathrm{R} 16$ & $\mathrm{C}_{2} \mathrm{H}+\mathrm{H}+\mathrm{M} \rightarrow \mathrm{C}_{2} \mathrm{H}_{2}+\mathrm{M}$ & $\begin{array}{l}k_{0}=1.26 \times 10^{-18} \mathrm{e}^{-721 / T} \\
k_{\infty}=3.0 \times 10^{-10}\end{array}$ & Tsang \& Hampson (1986) \\
\hline $\mathrm{R} 17$ & $\mathrm{C}_{2} \mathrm{H}+\mathrm{H}_{2} \rightarrow \mathrm{C}_{2} \mathrm{H}_{2}+\mathrm{H}$ & $5.58 \times 10^{-11} \mathrm{e}^{-1443 / T}$ & Opansky \& Leone (1996b) \\
\hline $\mathrm{R} 18$ & $\mathrm{C}_{2} \mathrm{H}+\mathrm{CH}_{4} \rightarrow \mathrm{C}_{2} \mathrm{H}_{2}+\mathrm{CH}_{3}$ & $6.94 \times 10^{-12} \mathrm{e}^{-250 / T}$ & Opansky \& Leone (1996a) \\
\hline R19 & $\mathrm{C}_{2} \mathrm{H}+\mathrm{C}_{2} \mathrm{H}_{6} \rightarrow \mathrm{C}_{2} \mathrm{H}_{2}+\mathrm{C}_{2} \mathrm{H}_{5}$ & $5.1 \times 10^{-11} \mathrm{e}^{-76 / \mathrm{T}}$ & Murhpy et al. (2003) \\
\hline $\mathrm{R} 20$ & $\mathrm{C}_{2} \mathrm{H}+\mathrm{C}_{2} \mathrm{H}_{2} \rightarrow \mathrm{C}_{4} \mathrm{H}_{2}+\mathrm{H}$ & $1.3 \times 10^{-10}$ & Vakhtin et al. (2001) \\
\hline $\mathrm{R} 21$ & $\mathrm{CH}_{3} \mathrm{C}_{2} \mathrm{H}+\mathrm{H} \rightarrow \mathrm{CH}_{3}+\mathrm{C}_{2} \mathrm{H}_{2}$ & $9.62 \times 10^{-12} \mathrm{e}^{-1560 / T}$ & Wagner \& Zellner (1972) \\
\hline $\mathrm{R} 22$ & $\mathrm{CH}_{3} \mathrm{C}_{2} \mathrm{H}+\mathrm{H}+\mathrm{M} \rightarrow{ }_{3} \mathrm{H}_{5}+\mathrm{M}$ & $\begin{array}{l}k_{0}=8.0 \times 10^{-24} T^{-2} \mathrm{e}^{-1225 / T} \\
k_{\infty}=9.7 \times 10^{-12} \mathrm{e}^{-1550 / T}\end{array}$ & $\begin{array}{l}\text { Yung et al. (1984) } \\
\text { Wang et al. (2000) }\end{array}$ \\
\hline $\mathrm{R} 23$ & $\mathrm{C}_{2} \mathrm{H}_{3}+\mathrm{C}_{2} \mathrm{H}_{3} \rightarrow \mathrm{C}_{2} \mathrm{H}_{4}+\mathrm{C}_{2} \mathrm{H}_{2}$ & $3.5 \times 10^{-11}$ & Laufer \& Fahr (2004) \\
\hline $\mathrm{R} 24$ & $\mathrm{C}_{2} \mathrm{H}_{3}+\mathrm{C}_{2} \mathrm{H}_{3}+\mathrm{M} \rightarrow \mathrm{C}_{4} \mathrm{H}_{6}+\mathrm{M}$ & $\begin{array}{l}k_{0}=2.822 \times 10^{-3} T^{-8.749} \mathrm{e}^{-985.4 / T} \\
k_{\infty}=9.5 \times 10^{-11}\end{array}$ & $\begin{array}{l}\text { Lavvas et al. (2008) } \\
\text { Laufer \& Fahr (2004) }\end{array}$ \\
\hline $\mathrm{R} 25$ & $\mathrm{C}_{4} \mathrm{H}+\mathrm{H}_{2} \rightarrow \mathrm{C}_{4} \mathrm{H}_{2}+\mathrm{H}$ & $1.20 \times 10^{-11} \mathrm{e}^{-998 / T}$ & Lavvas et al. (2008) \\
\hline $\mathrm{R} 26$ & $\mathrm{C}_{4} \mathrm{H}+\mathrm{CH}_{4} \rightarrow \mathrm{C}_{4} \mathrm{H}_{2}+\mathrm{CH}_{3}$ & $1.2 \times 10^{-11} \mathrm{e}^{-491 / T}$ & Lavvas et al. (2008) \\
\hline $\mathrm{R} 27$ & $\mathrm{C}_{4} \mathrm{H}+\mathrm{C}_{2} \mathrm{H}_{6} \rightarrow \mathrm{C}_{4} \mathrm{H}_{2}+\mathrm{C}_{2} \mathrm{H}_{5}$ & $5.1 \times 10^{-11} \mathrm{e}^{-76 / T}$ & Lavvas et al. (2008) \\
\hline $\mathrm{R} 28$ & $\mathrm{C}_{4} \mathrm{H}+\mathrm{H}+\mathrm{M} \rightarrow \mathrm{C}_{4} \mathrm{H}_{2}+\mathrm{M}$ & $\begin{array}{l}k_{0}=1.26 \times 10^{-18} T^{-3.1} \mathrm{e}^{-721 / T} \\
k_{\infty}=3.0 \times 10^{-10}\end{array}$ & Moses et al. (2000) \\
\hline $\mathrm{R} 29$ & $\mathrm{CH}_{4}+\mathrm{C}_{2} \mathrm{H}_{2} \rightarrow \mathrm{C}_{6} \mathrm{H}_{2}+\mathrm{H}$ & $1.3 \times 10^{-10}$ & Lavvas et al. (2008) \\
\hline $\mathrm{R} 30$ & $\mathrm{C}_{4} \mathrm{H}+\mathrm{C}_{4} \mathrm{H}_{2} \rightarrow \mathrm{C}_{8} \mathrm{H}_{2}+\mathrm{H}$ & $1.1 \times 10^{-10} \mathrm{e}^{28 / T}$ & Moses et al. (2000) \\
\hline $\mathrm{R} 31$ & $\mathrm{C}_{2} \mathrm{H}+\mathrm{C}_{4} \mathrm{H}_{2} \rightarrow \mathrm{C}_{6} \mathrm{H}_{2}+\mathrm{H}$ & $1.3 \times 10^{-10}$ & Lavvas et al. (2008) \\
\hline $\mathrm{R} 32$ & ${ }^{*} \mathrm{C}_{4} \mathrm{H}_{2}+\mathrm{C}_{4} \mathrm{H}_{2} \rightarrow \mathrm{C}_{8} \mathrm{H}_{2}+\mathrm{H}_{2}$ & $1.5 \times 10^{-10}$ & Zwier \& Allen (1996) \\
\hline R33 & $\mathrm{C}_{4} \mathrm{H}_{2}+\mathrm{H} \rightarrow \mathrm{C}_{4} \mathrm{H}_{3}$ & $1.4 \times 10^{-10} \mathrm{e}^{-1184 / T}$ & Schwanebeck \& Warnatz (1975); Nava et al. (1986) \\
\hline $\mathrm{R} 34 \mathrm{a}$ & $\mathrm{C}_{4} \mathrm{H}_{3}+\mathrm{H} \rightarrow \mathrm{C}_{4} \mathrm{H}_{2}+\mathrm{H}_{2}$ & $5.0 \times 10^{-12}$ & Wang \& Frenklach (1997) \\
\hline $\mathrm{R} 34 \mathrm{~b}$ & $\mathrm{C}_{4} \mathrm{H}_{3}+\mathrm{H} \rightarrow \mathrm{C}_{2} \mathrm{H}_{2}+\mathrm{C}_{2} \mathrm{H}_{2}$ & $1.5 \times 10^{-11}$ & Wang \& Frenklach (1997) \\
\hline $\mathrm{R} 35$ & $\mathrm{C}_{2}+\mathrm{H}_{2} \rightarrow \mathrm{C}_{2} \mathrm{H}+\mathrm{H}$ & $1.77 \times 10^{-10} \mathrm{e}^{-1469 / T}$ & Pitts et al. (1982) \\
\hline $\mathrm{R} 36$ & $\mathrm{C}_{2}+\mathrm{CH}_{4} \rightarrow \mathrm{C}_{2} \mathrm{H}+\mathrm{CH}_{3}$ & $5.05 \times 10^{-11} \mathrm{e}^{-297 / T}$ & Pitts et al. (1982) \\
\hline R37 & $\mathrm{C}_{2} \mathrm{H}+\mathrm{C}_{2} \mathrm{H}_{4} \rightarrow \mathrm{C}_{2} \mathrm{H}_{2}+\mathrm{C}_{2} \mathrm{H}_{3}$ & $1.8 \times 10^{-11} \mathrm{e}^{-302 / T}$ & from Lara et al. (1996) \\
\hline R38 & $\mathrm{C}_{4} \mathrm{H}+\mathrm{C}_{2} \mathrm{H}_{4} \rightarrow \mathrm{C}_{4} \mathrm{H}_{2}+\mathrm{C}_{2} \mathrm{H}_{3}$ & $1.4 \times 10^{-10}$ & Vakhtin et al. (2001) \\
\hline R39 & ${ }^{1} \mathrm{CH}_{2}+\mathrm{N}_{2} \rightarrow{ }^{3} \mathrm{CH}_{2}+\mathrm{N}_{2}$ & $7.9 \times 10^{-12}$ & Ashfold et al. (1981) \\
\hline $\mathrm{R} 40$ & ${ }^{3} \mathrm{CH}_{2}+{ }^{3} \mathrm{CH}_{2} \rightarrow \mathrm{C}_{2} \mathrm{H}_{2}+\mathrm{H}_{2}$ & $3.1 \times 10^{-10}$ & Baulch et al. (1992) \\
\hline R41 & $\mathrm{C}_{2} \mathrm{H}_{5}+\mathrm{CH}_{3} \rightarrow \mathrm{C}_{2} \mathrm{H}_{4}+\mathrm{CH}_{4}$ & $5.04 \times 10^{-14} T^{0.41} \mathrm{e}^{429 / T}$ & Zhu et al. (2004) \\
\hline $\mathrm{R} 42$ & $\mathrm{C}_{2} \mathrm{H}_{5}+\mathrm{CH}_{3}+\mathrm{M} \rightarrow \mathrm{C}_{3} \mathrm{H}_{8}+\mathrm{M}$ & $\begin{array}{l}k_{0}=2.822 \times 10^{-3} T^{-8.749} \mathrm{e}^{-985.4 / T} \\
k_{\infty}=2.41 \times 10^{-10} T^{-0.34} \mathrm{e}^{-259 / T}\end{array}$ & $\begin{array}{l}\text { Lavvas et al. (2008) } \\
\text { Zhu et al. (2004) }\end{array}$ \\
\hline $\mathrm{R} 43 \mathrm{a}$ & $\mathrm{C}_{2} \mathrm{H}_{5}+\mathrm{C}_{2} \mathrm{H}_{3} \rightarrow \mathrm{C}_{2} \mathrm{H}_{6}+\mathrm{C}_{2} \mathrm{H}_{2}$ & $2.81 \times 10^{-12}$ & Tsang \& Hampson (1986) \\
\hline $\mathrm{R} 43 \mathrm{~b}$ & $\mathrm{C}_{2} \mathrm{H}_{5}+\mathrm{C}_{2} \mathrm{H}_{3} \rightarrow \mathrm{C}_{2} \mathrm{H}_{4}+\mathrm{C}_{2} \mathrm{H}_{4}$ & $2.81 \times 10^{-12}$ & Tsang \& Hampson (1986) \\
\hline $\mathrm{R} 44$ & $\mathrm{C}_{2} \mathrm{H}_{5}+\mathrm{C}_{2} \mathrm{H}_{5} \rightarrow \mathrm{C}_{2} \mathrm{H}_{6}+\mathrm{C}_{2} \mathrm{H}_{4}$ & $2.3 \times 10^{-12}$ & Baulch et al. (1992) \\
\hline $\mathrm{R} 45$ & $\mathrm{C}_{2} \mathrm{H}_{5}+\mathrm{C}_{2} \mathrm{H}_{5}+\mathrm{M} \rightarrow \mathrm{C}_{4} \mathrm{H}_{10}+\mathrm{M}$ & $\begin{array}{l}k_{0}=6.723 \times 10^{-11} T^{-4.534} \\
k_{\infty}=1.8 \times 10^{-11}\end{array}$ & Laufer et al. (1983); Baulch et al. (1992) \\
\hline $\mathrm{R} 46$ & $\mathrm{C}_{3} \mathrm{H}_{3}+\mathrm{H}+\mathrm{M} \rightarrow \mathrm{CH}_{3} \mathrm{C}_{2} \mathrm{H}+\mathrm{M}$ & $\begin{array}{l}k_{0}=5.5 \times 10^{-27} \\
k_{\infty}=2.5 \times 10^{-10}\end{array}$ & $\begin{array}{l}\text { Moses et al. (2000) } \\
\text { Homann \& Wellmann (1983) }\end{array}$ \\
\hline
\end{tabular}


Table 1. continued.

\begin{tabular}{|c|c|c|c|}
\hline & Reaction & Rate coefficient & Reference \\
\hline $\bar{R} 47 \mathrm{a}$ & $\mathrm{C}_{3} \mathrm{H}_{5}+\mathrm{H} \rightarrow \mathrm{CH}_{3} \mathrm{C}_{2} \mathrm{H}+\mathrm{H}_{2}$ & $1.5 \times 10^{-11}$ & Hanning-Lee \& Pilling (1992) \\
\hline $\mathrm{R} 47 \mathrm{~b}$ & $\mathrm{C}_{3} \mathrm{H}_{5}+\mathrm{H} \rightarrow \mathrm{CH}_{2} \mathrm{CCH}_{2}+\mathrm{H}_{2}$ & $1.5 \times 10^{-11}$ & Hanning-Lee \& Pilling (1992) \\
\hline R48a & $\mathrm{C}_{3} \mathrm{H}_{5}+\mathrm{CH}_{3} \rightarrow \mathrm{CH}_{3} \mathrm{C}_{2} \mathrm{H}+\mathrm{CH}_{4}$ & $4.5 \times 10^{-12}$ & Tsang (1991) \\
\hline R48b & $\mathrm{C}_{3} \mathrm{H}_{5}+\mathrm{CH}_{3} \rightarrow \mathrm{CH}_{2} \mathrm{CCH}_{2}+\mathrm{CH}_{4}$ & $4.5 \times 10^{-12}$ & Tsang (1991) \\
\hline R49 & $\mathrm{C}_{3} \mathrm{H}_{2}+\mathrm{H}+\mathrm{M} \rightarrow \mathrm{C}_{3} \mathrm{H}_{3}+\mathrm{M}$ & $\begin{array}{l}k_{0}=2.52 \times 10^{-28} \\
k_{\infty}=5.0 \times 10^{-11}\end{array}$ & Moses et al. (2000) \\
\hline R50 & ${ }^{3} \mathrm{CH}_{2}+\mathrm{C}_{2} \mathrm{H}_{2} \rightarrow \mathrm{C}_{3} \mathrm{H}_{3}+\mathrm{H}$ & $2.00 \times 10^{-11} \mathrm{e}^{-3332 / T}$ & Tsang \& Hampson (1986) \\
\hline R51 & $\mathrm{C}_{3} \mathrm{H}_{8}+\mathrm{C}_{2} \mathrm{H} \rightarrow \mathrm{C}_{2} \mathrm{H}_{2}+\mathrm{C}_{3} \mathrm{H}_{7}$ & $9.8 \times 10^{-11} \mathrm{e}^{-71 / T}$ & Murhpy et al. (2003) \\
\hline R52 & $\mathrm{C}_{2} \mathrm{H}_{3}+\mathrm{CH}_{3}+\mathrm{M} \rightarrow \mathrm{C}_{3} \mathrm{H}_{6}+\mathrm{M}$ & $\begin{array}{l}k_{0}=6.0 \times 10^{-28} \mathrm{e}^{1680 / T} \\
k_{\infty}=1.2 \times 10^{-10}\end{array}$ & Fahr et al. (1991) \\
\hline R53 & $\mathrm{C}_{3} \mathrm{H}_{5}+\mathrm{H}+\mathrm{M} \rightarrow \mathrm{C}_{3} \mathrm{H}_{6}+\mathrm{M}$ & $\begin{array}{l}k_{0}=2.0 \times 10^{-28} \\
k_{\infty}=1.0 \times 10^{-11}\end{array}$ & $\begin{array}{l}\text { Moses et al. (2000) } \\
\text { Hanning-Lee \& Pilling (1992) }\end{array}$ \\
\hline R54 & $\mathrm{C}_{2} \mathrm{H}_{3}+\mathrm{CH}_{3} \rightarrow \mathrm{C}_{2} \mathrm{H}_{2}+\mathrm{CH}_{4}$ & $3.4 \times 10^{-11}$ & Fahr et al. (1991) \\
\hline R55 & $\mathrm{C}_{2} \mathrm{H}_{3}+\mathrm{C}_{2} \mathrm{H}_{5}+\mathrm{M} \rightarrow \mathrm{C}_{4} \mathrm{H}_{8}+\mathrm{M}$ & $\begin{array}{l}k_{0}=2.822 \times 10^{-3} T^{-8.749} \mathrm{e}^{-985.4 / T} \\
k_{\infty}=6.5 \times 10^{-11}\end{array}$ & $\begin{array}{l}\text { Lavvas et al. (2008) } \\
\text { Laufer \& Fahr (2004) }\end{array}$ \\
\hline R56 & $\mathrm{C}_{3} \mathrm{H}_{5}+\mathrm{CH}_{3}+\mathrm{M} \rightarrow \mathrm{C}_{4} \mathrm{H}_{8}+\mathrm{M}$ & $\begin{array}{l}k_{0}=2.822 \times 10^{-3} T^{-8.749} \mathrm{e}^{-985.4 / T} \\
k_{\infty}=1.55 \times 10^{-9} T^{-0.54} \mathrm{e}^{117 / T}\end{array}$ & $\begin{array}{l}\text { Lavvas et al. (2008) } \\
\text { Knyazev \& Slagle (2001) }\end{array}$ \\
\hline R57 & $\mathrm{C}_{4} \mathrm{H}_{2}+\mathrm{H}+\mathrm{M} \rightarrow \mathrm{C}_{4} \mathrm{H}_{3}+\mathrm{M}$ & $\begin{array}{l}k_{0}=1.0 \times 10^{-28} \\
k_{\infty}=1.39 \times 10^{-10} \mathrm{e}^{-1184 / T}\end{array}$ & $\begin{array}{l}\text { Schwanebeck \& Warnatz (1975) } \\
\text { Nava et al. (1986) }\end{array}$ \\
\hline $\begin{array}{l}\text { R58 } \\
\text { R59 }\end{array}$ & $\begin{array}{l}{ }^{*} \mathrm{C}_{4} \mathrm{H}_{2} \rightarrow \mathrm{C}_{4} \mathrm{H}_{2}+\mathrm{h} v \\
\mathrm{CH}+\mathrm{C}_{2} \mathrm{H}_{4} \rightarrow \mathrm{CH}_{3} \mathrm{C}_{2} \mathrm{H}+\mathrm{H}\end{array}$ & $\begin{array}{l}1.0 \times 10^{3} \\
3.87 \times 10^{-9} T^{-0.55} \mathrm{e}^{-29.6 / T}\end{array}$ & $\begin{array}{l}\text { Zwier \& Allen (1996) } \\
\text { Canosa et al. (1997) }\end{array}$ \\
\hline
\end{tabular}


Table 2. Hörst et al. (2008) C-H-O reactions.

\begin{tabular}{|c|c|c|c|}
\hline & Reaction & Rate coefficient & Reference \\
\hline R60 & $\mathrm{O}\left({ }^{1} \mathrm{~S}\right) \rightarrow \mathrm{O}\left({ }^{3} \mathrm{D}\right)$ & $1.3 \times 10^{0}$ & Koyano et al. (1975) \\
\hline R61 & $\mathrm{O}\left({ }^{1} \mathrm{D}\right) \rightarrow \mathrm{O}\left({ }^{3} \mathrm{P}\right)$ & $6.7 \times 10^{-3}$ & Okabe (1978) \\
\hline R62 & $\mathrm{O}\left({ }^{1} \mathrm{D}\right)+\mathrm{N}_{2} \rightarrow \mathrm{O}\left({ }^{3} \mathrm{P}\right)+\mathrm{N}_{2}$ & $2.2 \times 10^{-11} \mathrm{e}^{110 / T}$ & Sander et al. (2006) \\
\hline R63 & $\mathrm{O}\left({ }^{1} \mathrm{D}\right)+\mathrm{H}_{2} \rightarrow \mathrm{OH}+\mathrm{H}$ & $1.1 \times 10^{-10}$ & Sander et al. (2006) \\
\hline R64a & $\mathrm{O}\left({ }^{1} \mathrm{D}\right)+\mathrm{CH}_{4} \rightarrow \mathrm{OH}+\mathrm{CH}_{3}$ & $1.1 \times 10^{-10}$ & Sander et al. (2006) \\
\hline R64b & $\mathrm{O}\left({ }^{1} \mathrm{D}\right)+\mathrm{CH}_{4} \rightarrow \mathrm{CH}_{3} \mathrm{O}+\mathrm{H}$ & $3.0 \times 10^{-11}$ & Sander et al. (2006) \\
\hline R64c & $\mathrm{O}\left({ }^{1} \mathrm{D}\right)+\mathrm{CH}_{4} \rightarrow \mathrm{H}_{2} \mathrm{CO}+\mathrm{H}_{2}$ & $7.5 \times 10^{-12}$ & Sander et al. (2006) \\
\hline R65a & $\mathrm{O}\left({ }^{1} \mathrm{D}\right)+\mathrm{CO} \rightarrow \mathrm{O}\left({ }^{3} \mathrm{P}\right)+\mathrm{CO}$ & $4.7 \times 10^{-11} \mathrm{e}^{63 / T}$ & Davidson et al. (1978) \\
\hline \multirow[t]{2}{*}{ R65b } & $\mathrm{O}\left({ }^{1} \mathrm{D}\right)+\mathrm{CO} \rightarrow \mathrm{CO}_{2}$ & $8.0 \times 10^{-11}$ & Tully (1975) \\
\hline & & $1.0 \times 10^{-30}$ & Hörst et al. (2008) \\
\hline R66a & $\mathrm{O}\left({ }^{3} \mathrm{P}\right)+\mathrm{CH}_{3} \rightarrow \mathrm{HCHO}+\mathrm{H}$ & $6.9 \times 10^{-11}$ & Hack et al. (2005) \\
\hline R66b & $\mathrm{O}\left({ }^{3} \mathrm{P}\right)+\mathrm{CH}_{3} \rightarrow \mathrm{CO}+\mathrm{H}_{2}+\mathrm{H}$ & $5.7 \times 10^{-11}$ & Hack et al. (2005) \\
\hline R67a & $\mathrm{O}\left({ }^{3} \mathrm{P}\right)+\mathrm{HCO} \rightarrow \mathrm{CO}_{2}+\mathrm{H}$ & $5.0 \times 10^{-11}$ & Baulch et al. (1992) \\
\hline R67b & $\mathrm{O}\left({ }^{3} \mathrm{P}\right)+\mathrm{HCO} \rightarrow \mathrm{CO}+\mathrm{OH}$ & $5.0 \times 10^{-11}$ & Baulch et al. (1992) \\
\hline R68a & $\mathrm{O}\left({ }^{3} \mathrm{P}\right)+\mathrm{CH}_{3} \mathrm{CO} \rightarrow \mathrm{CO}_{2}+\mathrm{CH}_{3}$ & $2.6 \times 10^{-10}$ & Baulch et al. (1992) \\
\hline R68b & $\mathrm{O}\left({ }^{3} \mathrm{P}\right)+{ }^{1} \mathrm{CH}_{2} \rightarrow \mathrm{CH}_{2} \mathrm{CO}+\mathrm{OH}$ & $6.4 \times 10^{-11}$ & Baulch et al. (1992) \\
\hline R69 & $\mathrm{OH}+\mathrm{H}_{2} \rightarrow \mathrm{H}_{2} \mathrm{O}+\mathrm{H}$ & $7.7 \times 10^{-12} \mathrm{e}^{-2100 / T}$ & Atkinson et al. (2004) \\
\hline R70 & $\mathrm{OH}+{ }^{3} \mathrm{CH}_{2} \rightarrow \mathrm{HCHO}+\mathrm{H}$ & $3.0 \times 10^{-11}$ & Tsang \& Hampson (1986) \\
\hline \multirow[t]{2}{*}{ R71a } & $\mathrm{OH}+\mathrm{CH}_{3} \rightarrow \mathrm{H}_{2} \mathrm{O}+{ }^{1} \mathrm{CH}_{2}$ & $6.4 \times 10^{-8} \mathrm{~T}^{5.8} \mathrm{e}^{485 / \mathrm{T}}$ & Pereira et al. (1997) \\
\hline & & $1.8 \times 10^{-8} T^{-0.91} \mathrm{e}^{-275 / T}$ & Pereira et al. (1997) \\
\hline \multirow[t]{2}{*}{$\mathrm{R} 71 \mathrm{~b}$} & $\mathrm{OH}+\mathrm{CH}_{3} \rightarrow \mathrm{HCHO}+\mathrm{H}_{2}$ & $1.1 \times 10^{-17} T^{8.0} \mathrm{e}^{1240 / T}$ & Pereira et al. (1997) \\
\hline & & $3.8 \times 10^{-14} T^{-0.12} \mathrm{e}^{209 / T}$ & Pereira et al. (1997) \\
\hline \multirow[t]{2}{*}{ R71c } & $\mathrm{OH}+\mathrm{CH}_{3} \rightarrow \mathrm{CH}_{3} \mathrm{OH}$ & $7.2 \times 10^{-9} T^{-0.79}$ & Pereira et al. (1997) \\
\hline & & $1.1 \times 10^{-10} T^{-6.21} e^{-671 / T}$ & Pereira et al. (1997) \\
\hline R72 & $\mathrm{OH}+\mathrm{CH}_{4} \rightarrow \mathrm{H}_{2} \mathrm{O}+\mathrm{CH}_{3}$ & $1.9 \times 10^{-12} \mathrm{e}^{-1690 / T}$ & Atkinson et al. (2006) \\
\hline \multirow[t]{2}{*}{ R73 } & $\mathrm{OH}+\mathrm{C}_{2} \mathrm{H}_{2} \rightarrow \mathrm{CH}_{3} \mathrm{CO}$ & $9.2 \times 10^{-18} T^{2}$ & Sander et al. (2006) \\
\hline & & $5.5 \times 10^{-30}$ & Sander et al. (2006) \\
\hline \multirow[t]{2}{*}{ R74 } & $\mathrm{OH}+\mathrm{C}_{2} \mathrm{H}_{4} \rightarrow \mathrm{HOCH}_{2} \mathrm{CH}_{2}$ & $1.1 \times 10^{-9} T^{-0.85}$ & Sander et al. (2006) \\
\hline & & $1.4 \times 10^{-17} T^{-4.5}$ & Sander et al. (2006) \\
\hline R75a & $\mathrm{OH}+\mathrm{CO} \rightarrow \mathrm{CO}_{2}+\mathrm{H}$ & $1.4 \times 10^{-13}\left(1+\left[N_{2}\right] / 4.2 \times 10^{19}\right)$ & Atkinson et al. (2006) \\
\hline \multirow[t]{2}{*}{ R75b } & $\mathrm{OH}+\mathrm{CO} \rightarrow \mathrm{HOCO}$ & $1.8 \times 10^{-9} T^{-1.3}$ & Sander et al. (2006) \\
\hline & & $2.0 \times 10^{-36} T^{1.4}$ & Sander et al. (2006) \\
\hline R76 & $\mathrm{HCO}+\mathrm{H} \rightarrow \mathrm{CO}+\mathrm{H}_{2}$ & $1.5 \times 10^{-10}$ & Baulch et al. (1992) \\
\hline R77 & $\mathrm{HCO}+\mathrm{CH}_{3} \rightarrow \mathrm{CO}+\mathrm{CH}_{4}$ & $2.0 \times 10^{-10}$ & Tsang \& Hampson (1986) \\
\hline $\mathrm{R} 78$ & $\mathrm{CH}_{3} \mathrm{O}+\mathrm{H} \rightarrow \mathrm{HCHO}+\mathrm{H}_{2}$ & $3.0 \times 10^{-11}$ & Baulch et al. (1992) \\
\hline R79 & $\mathrm{CH}_{3} \mathrm{O}+\mathrm{CH}_{3} \rightarrow \mathrm{HCHO}+\mathrm{CH}_{4}$ & $4.0 \times 10^{-11}$ & Tsang \& Hampson (1986) \\
\hline R80a & $\mathrm{CH}_{3} \mathrm{CO}+\mathrm{CH}_{3} \rightarrow \mathrm{CO}+\mathrm{C}_{6} \mathrm{H}_{6}$ & $5.4 \times 10^{-11}$ & Adachi et al. (1981) \\
\hline R80b & $\mathrm{CH}_{3} \mathrm{CO}+\mathrm{CH}_{3} \rightarrow \mathrm{CH}_{2} \mathrm{CO}+\mathrm{CH}_{4}$ & $1.0 \times 10^{-11}$ & Hassinen et al. (1990) \\
\hline \multirow[t]{2}{*}{ R80c } & $\mathrm{CH}_{3} \mathrm{CO}+\mathrm{CH}_{3} \rightarrow \mathrm{CH}_{3} \mathrm{COCH}_{3}$ & $7.0 \times 10^{-11}$ & Hassinen et al. (1990) \\
\hline & & $1.0 \times 10^{-30}$ & Hörst et al. (2008) \\
\hline $\mathrm{R} 81$ & $\mathrm{C}_{2} \mathrm{H}+\mathrm{H}_{2} \mathrm{O} \rightarrow \mathrm{OH}+\mathrm{C}_{2} \mathrm{H}_{2}$ & $2.1 \times 10^{-12} \mathrm{e}^{-200 / T}$ & Vanlook \& Peeters (1995) \\
\hline
\end{tabular}


ঔ̊

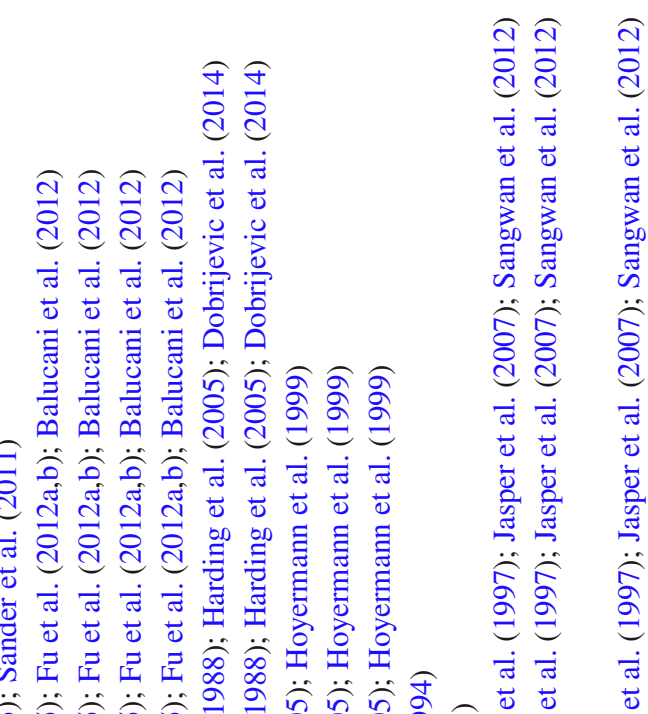

.0 .

$\frac{5}{8}$

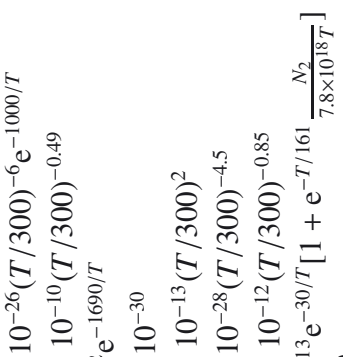

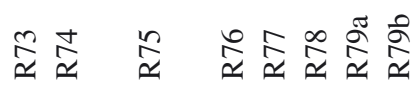




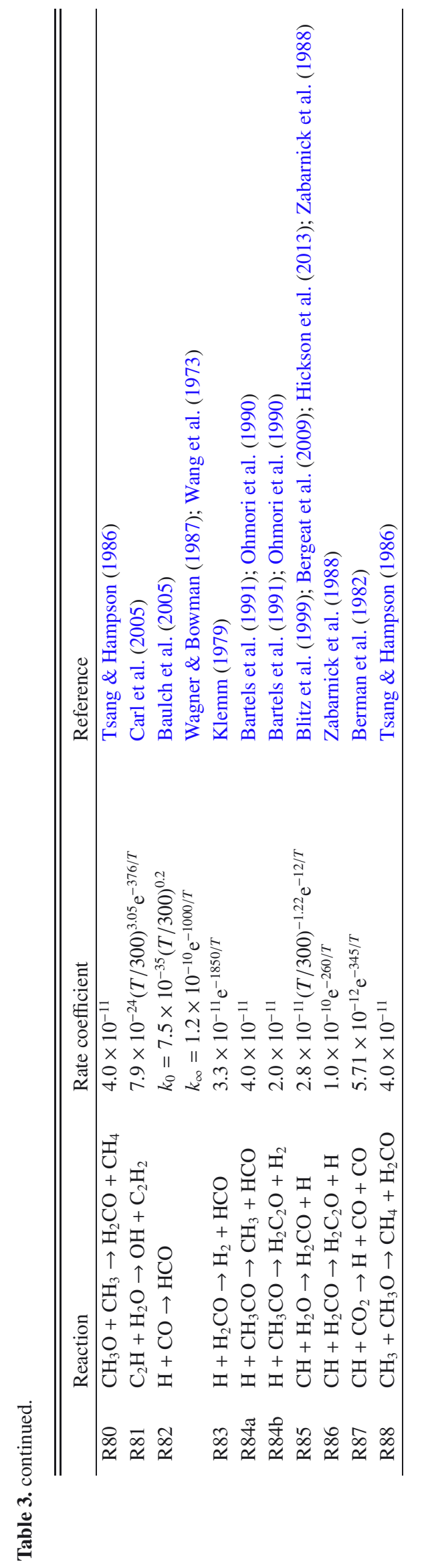

